\title{
立体骨組構造物の有限変位解析* \\ FINITE DISPLACEMENT ANALYSIS OF SPACE FRAMED STRUCTURES
}

\author{
前田幸 雄** - 林正*** \\ By Yukio MAEDA and Masa HAYASHI
}

\section{1. 緒 言}

マトリックス法による構造物の幾何学的非線形解析に ついては, 数多くの寸ぐれた研究成果が報告されてい る. 骨組構造物の立体解析についても多くの論文が発表 されているが，3 次元空間における有限変位の考え方が 不十分であるために, 厳密な立体有限変位解析は行われ ていない1) 5). すなわち，3次元空間における有限な回 転はベクトル則には従わないにもかかわらず，回転がべ クトル的に取り扱われている．したがって，座標変換が 正しく行われていないので, 適合条件と平衡条件とが峳 密には満足されていない.

薄肉断面部材については, 精度の高い弾性方程式が報 告されている(6),7). しかし, これらの式を, 多数の部材 から構成される立体構造物に適用するためには, 適合条 件と平衡条件を弾性方程式と同程度以上の精度で求めて おかなければならない。 また，これらの論文において示 された変位関数には有限な回転による連成項が含まれて おらず，回転に関しては線形化有限変位理論といえるも のである.

立体骨組構造物の幾何学的非線形問題を扱った研究の なかで, Tezcan \& Mahapatra ${ }^{2)}$, Chu \& Rampetsrei$\operatorname{ter}^{3)}$, 結城・前田 ${ }^{4)}$ な゙は, コード・アングル (chord angle）を修正することにより変形後の部材座標系を定 めて, 材端変位と材端力を求めている.このとき, 変形 後の部材の両端でそれぞれ異なった変換行列を用いてた わみ角を求めて抢り，材端力の算出に矛盾がある21,3). 文献 4) の研究ではこの点が改良されているが，曲げ変 形により部材の両端の断面主軸が平行にならないことが

\footnotetext{
* 日本鋼構造協会第 9 回マトリックス構造解析法研究発表会 （昭和 50 年 6 月）にて一部発表済

** 正会員 工博 大阪大学教授 工学部土木工学科

*** 正会員大阪大学講師 工学部土木工学科
}

考慮されていない.さらに, 上記のいずれの研究におい ても，節点回転角を有限な回転として扱っていない欠点 がある。

上記の研究に対し, Oran の研究5) は注目すべきもの であって, 全体座標系に関する節点の回転量から変形後 の部材の両端における方向余弦を求め, これからたわみ 角を求めている。このとき, 回転運動が大きいときには 回転量はベクトルとしては表現できないことに着目し， 回転行列注1) 用いて変形後の部材端の方向余弦を導い ている.しかしながら, 具体的に与えられた回転行列は 微小回転に対する式であって, 有限な回転に対する式で はない，さらに，たわみ角とねじれ角を求めるときに近 似式が用いられていることと, 変形後の部材の座標変換 行列注2) が両端における方向余弦の平均值として与えら れていることなどによる䛊差が，大変位問題では無視で きないものと思われる.

本論文では, 有限な回転に対する回転行列を用いて厳 密な回転の合成手順を説明し，これを用いて精度の高い 座標変換行列と部材端変位の表示式を示す.この計算式 を用いれば，非線形方程式を解くための NewtonRaphson 法の収束性が良くなることを, 数值計算例に より示す.

忘力と変位の関係を表わす非線形の剛性行列は, 前述

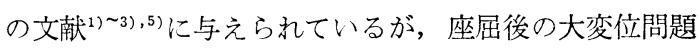
に適用するには十分な精度を有していないと思われる。 文献 ${ }^{4)}$ では, 薄肉断面の棒部材に対する剛性行列の誘導 過程が詳細に説明されているが，具体的な式は示されて いない，そこで，本文ではエネルギー原理に基づいて， 曲げねじりの影響を無視した場合の剛性行列を求めた。

エネルギー原理に基づいた有限要素法を用いる場合， 変位場の仮定が極めて重要であることは, しばしば指摘

注 1) 原論文5)では, joint orientation matrix とよばれてい る.

注 2) 同じく, member orientation matrix とよばれている. 
されている7) 9)．有限な回転場における変位には，回転 の 3 成分の連成項が含まれるが，このような変位場は過 去の研究では用いられていない。この理由は, 棒理論に おける断面不変の仮定から導かれた変位とひずみの関係 式において, 部材軸方向の変位の微倸数の 2 次項を省略 したことによるものであり，軸方向の変位を含まない微 分方程式の解として求められた変位には, 上述の連成項 は現われない。これは，明らかに厳密な有限变位とはい えないものである. 本文の終りにおいて, 棒理論におけ る断面不変の仮定とベルヌーイの仮定のもとに，過去の 論文で報告された変位より精度の高い有限変位を示し た。また, 従来の研究において省略されている軸方向変 位の微係数の 2 次項は，すべてを省略することができな いことを数值計算例により指摘する.

\section{2. 有限 回転}

\section{（1） 3 次元空間における有限变位}

剛体の空間運動に関する基本的な性質により，有限な 変位は平行移動と回転とに分けることができる.このう ち, 平行移動は一つのベクトルとして表わすことができ るので, その取り扱いについては問題はない。しかし, 有限な回転は微小回転のようにベクトル的な合成はでき ない，すなわち，2つの回転を合成する際，合成の順序 を変えると結果が異なるために可換則が成立しない，そ こで，本文では回転変位を合成するために回転行列 ${ }^{10)}$ 用いることにする.

節点の回転を求めるために, 節点に固定され節点とと もに回転する直交座標系を考える．この座標系の変形前 の基本ベクトルを $i, j, k$ とし，回転後のそれらを $i^{*}$, $j^{*}, \boldsymbol{k}^{*}$ と寸れば，これらの間には回転行列 $\boldsymbol{R}$ を用いて 次の関係式が成立つ.

$$
i^{*}=R i, j^{*}=R j, k^{*}=R k
$$

ここに,

$$
\boldsymbol{R}=\left[\begin{array}{lll}
r_{11} & r_{12} & r_{13} \\
r_{21} & r_{22} & r_{23} \\
r_{31} & r_{32} & r_{33}
\end{array}\right]
$$

であって, 第 1 列目の要素 $r_{i 1}(i=1,2,3)$ は直交座標 系 $\boldsymbol{i}, \boldsymbol{j}, \boldsymbol{k}$ に対する $\boldsymbol{i}^{*}$ の, 第 2,3 列目の要素はそれ ぞれ $\boldsymbol{j}^{*}, \boldsymbol{k}^{*}$ の方向余弦を表わす. したがって, 回転前 に $\boldsymbol{p}_{0}$ なるべクトルが回転 $R_{1}$ により $\boldsymbol{p}_{1}$ になったとす れば

$$
p_{1}=R_{1} p_{0}
$$

と表わすことができる. 引続いて $n$ 回の回転 $R_{2}, R_{3}, \cdots$, $R_{n}$ を行った後のベクトル $\boldsymbol{p}_{n}$ は，次のようになる.

$$
\boldsymbol{p}_{n}=\boldsymbol{R}_{n} \boldsymbol{p}_{n-1}=\left(\boldsymbol{R}_{n} \boldsymbol{R}_{n-1} \cdots \boldsymbol{R}_{2} \boldsymbol{R}_{1}\right) \boldsymbol{p}_{0}
$$

微小回転の場合には, 回転ベクトルの各成分を $\left(\Delta \theta_{X}\right.$,
$\left.\Delta \theta_{\boldsymbol{Y}}, \Delta \theta_{Z}\right)$ とすれば，式（2）の回転行列は定義よりた だちに次式で与えられる.

$$
\Delta \boldsymbol{R}=\left[\begin{array}{ccc}
1 & -\Delta \theta_{Z} & \Delta \theta_{Y} \\
\Delta \theta_{Z} & 1 & -\Delta \theta_{X} \\
-\Delta \theta_{Y} & \Delta \theta_{X} & 1
\end{array}\right] .
$$

式（4）を用いて微小回転の合成を行らとき, 2 次の微 小項を省略すれば合成結果は回転の順序によらないこと がわかる.すなわち，

$$
\Delta \boldsymbol{R}_{2} \Delta \boldsymbol{R}_{1} \doteqdot \Delta \boldsymbol{R}_{1} \Delta \boldsymbol{R}_{2}
$$

ところが，式 (5) で与えられる回転行列は正規直交行 列ではなく，また式 (6)によって回転を合成していくと 合成結果には誤差が累積されていく.そこで, 有限な回 転に対する回転行列を以下の上うにして求める.

\section{(2) 回転行列}

剛体の回転に関するオイラーの定理 ${ }^{10}$ により，節点は ある空間ベクトル $\phi$ を中心として有限な角 $\alpha$ だけ回転 する.いま，このベクトルの全体座標系に対する方向余 弦を $\left(\phi_{X}, \phi_{Y}, \phi_{Z}\right)$ とし，その大きさ $|\boldsymbol{\phi}|$ が $\alpha$ に等し くなるように成分 $\left(\theta_{X}, \theta_{Y}, \theta_{Z}\right)$ を定めると注), 次の関 係式が成り立つ.

$$
\begin{aligned}
& \left(\phi_{X}, \phi_{Y}, \phi_{Z}\right)=\left(\theta_{X} / \alpha, \theta_{Y} / \alpha, \theta_{Z} / \alpha\right) \\
& \alpha^{2}=\theta_{X}+\theta_{Y}^{2}+\theta_{Z}^{2}
\end{aligned}
$$

図一1 に示すように, ベクトル $\phi$ の方向に単位ベク トル $e_{3}$ をとり, 2 つの単位ベクトル $e_{1}, e_{2}$ を $e_{3}$ と直 交右手系をなすように定める.

節点に固定された任意のベクトル $r$ を

$$
\boldsymbol{r}=r_{1} \boldsymbol{e}_{1}+r_{2} \boldsymbol{e}_{2}+r_{3} \boldsymbol{e}_{3}
$$

と表わせば， $\phi$ を回転軸とし，角 $\alpha$ だけ回転した後の ベクトル $r^{*}$ は

$$
\boldsymbol{r}^{*}=\left(r_{1} \cos \alpha-r_{2} \sin \alpha\right) \boldsymbol{e}_{1}+\left(r_{1} \sin \alpha+r_{2} \cos \alpha\right) \boldsymbol{e}_{2}+r_{3} \boldsymbol{e}_{3}
$$

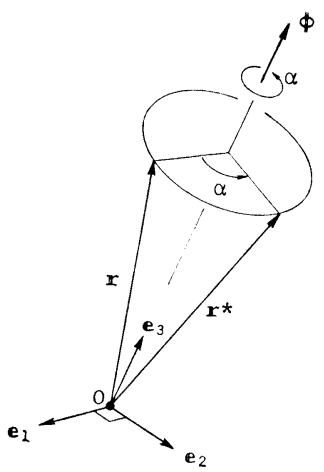

Fig. 1 Rotation of vector

注）回転は大きさと方向をもつ量であるが，ベクトルとして 表現できない，したがって，方向を表わす $\phi$ の大きさが 回転の大きさ $\alpha$ ではないので, $\phi$ の大きさ任意でよ い.ただし，微小回転は 1 つのベクトルとして表現でき る. 
となる. 上式を変形して

$\boldsymbol{r}^{*}=\boldsymbol{r} \cos \alpha+r_{8}(1-\cos \alpha) \boldsymbol{e}_{3}+\left(r_{1} \boldsymbol{e}_{2}-r_{2} \boldsymbol{e}_{1}\right) \sin \alpha \cdots$ (11)

さらに, ベクトルとディアード (dyad) のスカラー 積注1)を用いて変形する. このとき, 基本ベクトルの性 質老考慮寸机次式の上うになる。

$\boldsymbol{r}^{*}=\left[\boldsymbol{E} \operatorname{ccs} \alpha+(1-\cos \alpha) \boldsymbol{e}_{3} \boldsymbol{e}_{3}+\left(\boldsymbol{e}_{2} \boldsymbol{e}_{1}-\boldsymbol{e}_{1} \boldsymbol{e}_{2}\right) \sin \alpha\right] \cdot \boldsymbol{r}$

ここに, $E$ は単位行列, $e_{3} e_{3}, e_{2} e_{1}, e_{1} e_{2}$ はディアード を表わす.

$\boldsymbol{E}$ は単位ベクトルのディアディック (dyadic) を用い て表わすことができるから注2)，知とのべクトル積注1)を とると

$$
\begin{aligned}
\boldsymbol{e}_{3} \times \boldsymbol{E} & =\left(\boldsymbol{e}_{3} \times \boldsymbol{e}_{1}\right) \boldsymbol{e}_{1}+\left(\boldsymbol{e}_{3} \times \boldsymbol{e}_{2}\right) \boldsymbol{e}_{2}+\left(\boldsymbol{e}_{3} \times \boldsymbol{e}_{3}\right) \boldsymbol{e}_{3} \\
& =\boldsymbol{e}_{2} \boldsymbol{e}_{1}-\boldsymbol{e}_{1} \boldsymbol{e}_{2}
\end{aligned}
$$

の関倸式を導くことができる.

\section{式（13）を式（12）に代入すると}

$\boldsymbol{r}^{*}=\left[\boldsymbol{E} \cos \alpha+(1-\cos \alpha) \boldsymbol{e}_{3} \boldsymbol{e}_{3}+\boldsymbol{e}_{3} \times \boldsymbol{E} \sin \alpha\right] \cdot \boldsymbol{r} \cdots$ (14)

となる.したがって, 有限な回転に対する回転行列, 式 （2）は次式で与えられる.

$\boldsymbol{R}=\boldsymbol{E} \cos \alpha+(1-\cos \alpha) \boldsymbol{e}_{3} \boldsymbol{e}_{3}+\boldsymbol{e}_{3} \times \boldsymbol{E} \sin \alpha$

この行列 $\boldsymbol{R}$ は正規直交行列であり, 次の関倸式を満 足している.

$$
\boldsymbol{R} \boldsymbol{R}^{T}=\boldsymbol{R}^{T} \boldsymbol{R}=\boldsymbol{E}
$$

ここに, $\boldsymbol{R}^{T}$ は転置行列を表わす.また, 回転の向きが 逆の回転行列, 寸なわち式 (15) に胠いて 対にしたものは, もとの行列の逆行列になる.

角 $\alpha$ が微小な場合には, 微小回転ベクトル

$$
\Delta \phi=\left(\Delta \theta_{X}, \Delta \theta_{Y}, \Delta \theta_{Z}\right)
$$

を用いると, 式 (15) の $\boldsymbol{R}$ は

$$
\Delta \boldsymbol{R} \fallingdotseq \boldsymbol{E}+\boldsymbol{e}_{3} \times \boldsymbol{E} \Delta \alpha=\boldsymbol{E}+\Delta \boldsymbol{\phi} \times \boldsymbol{E}
$$

となり，式（5）に一致することがわかる.この式 (18) を式（4）に代入して微小回転の合成を行うときに，2次 以上の微小項を省略すればベクトルの合成則が成り立 ち, 行列河換となることがわかる.

$$
\begin{aligned}
\Delta \boldsymbol{R}_{n} \cdots \Delta \boldsymbol{R}_{2} \Delta \boldsymbol{R}_{1} & \fallingdotseq \boldsymbol{E}+\left(\Delta \boldsymbol{\phi}_{1}+\Delta \boldsymbol{\phi}_{2}+\cdots+\Delta \boldsymbol{\phi}_{n}\right) \times \boldsymbol{E} \cdots(19) \\
& \fallingdotseq \Delta \boldsymbol{R}_{1} \Delta \boldsymbol{R}_{2} \cdots \Delta \boldsymbol{R}_{n} \cdots \cdots \cdots \cdots \cdots \cdots \cdots \cdots(20)
\end{aligned}
$$

さて, 式（15）の各要素を求めるために, 右辺の第 3 項を展開する注3).

$$
\begin{aligned}
\boldsymbol{e}_{3} \times \boldsymbol{E} & =\phi_{X}(\boldsymbol{k} \boldsymbol{j}-\boldsymbol{j} \boldsymbol{k})+\phi_{Y}(\boldsymbol{i k}-\boldsymbol{k i})+\phi_{Z}(\boldsymbol{j i}-\boldsymbol{i} \boldsymbol{j}) \\
& =\left[\begin{array}{ccc}
0 & -\phi_{Z} & \phi_{Y} \\
\phi_{Z} & 0 & -\phi_{X} \\
-\phi_{Y} & \phi_{X} & 0
\end{array}\right] \ldots \ldots \ldots \ldots \ldots \ldots \ldots \ldots \ldots \ldots \ldots \ldots \ldots \ldots \ldots \ldots
\end{aligned}
$$

ゆえに, 式 (15) の回転行列, 寸なわち式 (2) の各要

$$
\text { 注 1) } \begin{aligned}
\boldsymbol{a} \text { をべクトル, } \boldsymbol{b} \boldsymbol{c} \text { をディアードとすると, } \\
\boldsymbol{a} \cdot(\boldsymbol{b} \boldsymbol{c})=(\boldsymbol{a} \cdot \boldsymbol{b}) \boldsymbol{c} \\
\boldsymbol{a} \times(\boldsymbol{b} \boldsymbol{c})=(\boldsymbol{a} \times \boldsymbol{b}) \boldsymbol{c}
\end{aligned}
$$$$
\text { 注 2) } \boldsymbol{E}=\boldsymbol{e}_{1} \boldsymbol{e}_{1}+\boldsymbol{e}_{2} \boldsymbol{e}_{2}+\boldsymbol{e}_{3} \boldsymbol{e}_{3}
$$

注 3）全体座標系で表わせば

$$
\boldsymbol{e}_{3}=\phi_{X} \boldsymbol{i}+\phi_{Y} \boldsymbol{j}+\phi_{Z} \boldsymbol{k}
$$$$
\boldsymbol{E}=\boldsymbol{i} \boldsymbol{i}+\boldsymbol{j} \boldsymbol{j}+\boldsymbol{k} \boldsymbol{k}
$$

素は次のようになる.

$$
\left.\begin{array}{l}
r_{11}=\phi_{X}^{2}(1-\cos \alpha)+\cos \alpha \\
r_{21}=\phi_{Y} \phi_{X}(1-\cos \alpha)+\phi_{Z} \sin \alpha \\
r_{31}=\phi_{Z} \phi_{X}(1-\cos \alpha)-\phi_{Y} \sin \alpha \\
r_{12}=\phi_{X} \phi_{Y}(1-\cos \alpha)-\phi_{Z} \sin \alpha \\
r_{22}=\phi_{Y}{ }^{2}(1-\cos \alpha)+\cos \alpha \\
r_{32}=\phi_{Z} \dot{\phi}_{Y}(1-\cos \alpha)+\phi_{X} \sin \alpha \\
r_{13}=\phi_{X} \phi_{Z}(1-\cos \alpha)+\phi_{Y} \sin \alpha \\
r_{23}=\phi_{Y} \phi_{Z}(1-\cos \alpha)-\dot{\phi}_{X} \sin \alpha \\
r_{33}=\phi_{Z}{ }^{2}(1-\cos \alpha)+\cos \alpha
\end{array}\right\}
$$

\section{3. 部材座標系と材端変位}

立体骨組部材は曲げとねじりの作用を受けて変形し, さらに剛体的な回転を伴らために変形後の部材座標軸が 簡単には求められない. 本節では, 部材両端の節点の変 形後の座標值と回転とから部材座標軸を定め, この座標 系で表わした部材端変位を求める.

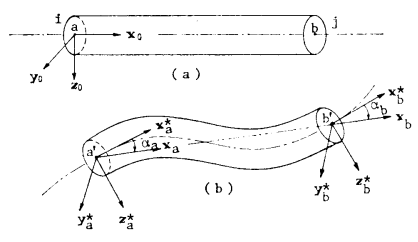

Fig. 2 Member coordinates

\section{(1) 部材座標系}

節点 $i$ に $a$ 端, 節点 $j$ に $b$ 端を持つ直線部材にお いて, 断面の重心点 $a, b$ を結ぶ直線を変形前後の部材 座標の $x$ 軸とし, この $x$ 軸と直交右手系をなすように $y, z$ 軸を定める. 変形前において $y, z$ 軸を断面の主軸 方向に定め注), この部材座標系を全体座標系に変換する 行列を $\boldsymbol{T}_{0}$ で表わす. いま, 部材の両端 $a, b$ に固定さ れ, 変形前の部材軸の方向と一致する 2 組の正規直交系 を考える、節点の回転により，この 2 組の直交系は変形 後それぞれ $\left(\boldsymbol{x}_{a}{ }^{*}, \boldsymbol{y}_{a}{ }^{*}, \boldsymbol{z}_{a}{ }^{*}\right),\left(\boldsymbol{x}_{b}{ }^{*}, \boldsymbol{y}_{b}{ }^{*}, \boldsymbol{z}_{b}{ }^{*}\right)$ になった ものとする.これらの座標軸の方向余弦でつくった行列 をそれぞれ $\boldsymbol{T}_{a}{ }^{*}, \boldsymbol{T}_{b}{ }^{*}$ とすると，節点 $i, j$ の回転行列 $\boldsymbol{R}_{i}, \boldsymbol{R}_{j}$ を用いて次のように表わせる.

$$
T_{a}^{*}=R_{i} T_{0}, T_{b}^{*}=R_{j} T_{0}
$$

まず $a$ 端において, 変形後の $x$ 軸上に単位ベクトル $\boldsymbol{x}_{a}$ を考え, $\boldsymbol{x}_{a}$ * となす角を $\alpha_{a}$ とする. そして, $\boldsymbol{x}_{a}{ }^{*}$ と $\boldsymbol{x}_{a}$ とに值交する軸を回転軸として, 直交系 $\left(\boldsymbol{x}_{a}{ }^{*}\right.$, $\left.\boldsymbol{y}_{a}{ }^{*}, \boldsymbol{z}_{a}{ }^{*}\right)$ を角 $\alpha_{a}$ だけ回転させて $\boldsymbol{x}_{a}{ }^{*}$ を $\boldsymbol{x}_{a}$ に一致 させる.このとき, $\boldsymbol{y}_{a}{ }^{*}$ および $\boldsymbol{z}_{a}{ }^{*}$ はそれぞれ $\boldsymbol{y}_{a}$ お よび $z_{a}$ になったものとする. この回転軸の方向に単位 ベクトル $\phi_{a}$ を考えると,

$$
\boldsymbol{x}_{a}{ }^{*} \times \boldsymbol{x}_{a}=\boldsymbol{\phi}_{a} \sin \alpha_{a} \cdots
$$

注）このとき，コード・フングルを用いると便利である゙1). 
となるから，この回転を表わす行列 $\boldsymbol{R}_{a}$ を $\boldsymbol{x}_{a} *$ と $\boldsymbol{x}_{a}$ と のスカラー積とベクトル積を用いて表わすことができ る.すなわち，式 (15) より

$$
\begin{aligned}
\boldsymbol{R}_{a}=\left(\boldsymbol{x}_{a}{ }^{*} \cdot \boldsymbol{x}_{a}\right) \boldsymbol{E} & +\frac{\left(\boldsymbol{x}_{a}{ }^{*} \times \boldsymbol{x}_{a}\right)\left(\boldsymbol{x}_{a}{ }^{*} \times \boldsymbol{x}_{a}\right)}{1+\left(\boldsymbol{x}_{a} * \cdot \boldsymbol{x}_{a}\right)} \\
& +\left(\boldsymbol{x}_{a}{ }^{*} \times \boldsymbol{x}_{a}\right) \times \boldsymbol{E}
\end{aligned}
$$

となる. したがって, $\left(\boldsymbol{x}_{a}, \boldsymbol{y}_{a}, \boldsymbol{z}_{a}\right)$ の方向余弦でっくっ た行列 $\boldsymbol{T}_{a}$ は, 式 (25) より次のように表わせる.

$$
\begin{aligned}
\boldsymbol{T}_{a} & =\boldsymbol{R}_{a} \boldsymbol{T}_{a}{ }^{*} \\
& \equiv \boldsymbol{\Phi}_{a} \boldsymbol{T}_{\mathbf{0}}\left(\boldsymbol{\Phi}_{a}=\boldsymbol{R}_{a} \boldsymbol{R}_{i}\right)
\end{aligned}
$$

$b$ 端においても同様にして, $\left(\boldsymbol{x}_{b}, \boldsymbol{y}_{b}, z_{b}\right)$ なる直交系 を考えると，

$$
\boldsymbol{T}_{b}=\Phi_{b} \boldsymbol{T}_{\mathbf{0}}\left(\boldsymbol{\Phi}_{b}=\boldsymbol{R}_{b} \boldsymbol{R}_{j}\right)
$$

$a$ および $b$ 端において, ベクトル $\boldsymbol{y}_{a}$ と $z_{a}$ および $\boldsymbol{y}_{b}$ と $z_{b}$ とが作る平面は互いに平行であるから, 角

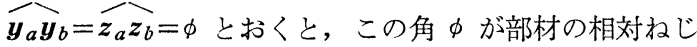

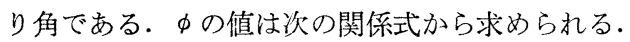

$$
\left.\begin{array}{r}
\boldsymbol{y}_{a} \cdot \boldsymbol{y}_{b}=\boldsymbol{z}_{a} \cdot \boldsymbol{z}_{b}=\cos \phi \\
-\boldsymbol{y}_{a} \cdot \boldsymbol{z}_{b}=\boldsymbol{z}_{a} \cdot \boldsymbol{y}_{b}=\sin \dot{\phi}
\end{array}\right\}
$$

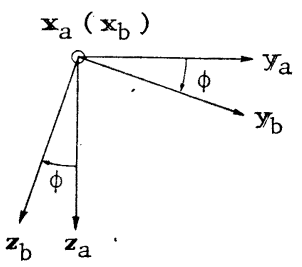

Fig. 3 Angle of torsion

変形後の $y, z$ 軸を定めるために, $a, b$ 両端の权じり 角 $\theta_{a}{ }^{*}, \theta_{b} *$ を絶対值が等しく符号が反対になるように 選ぶ.

$$
-\theta_{a}{ }^{*}=\theta_{b}{ }^{*}=\phi / 2 \equiv \theta .
$$

このように定めると, 変形後の部材座標は一義的に決 定される. 変形後の座標変換行列 $\boldsymbol{T}$ は $\boldsymbol{T}_{0}$ より変換し $\tau$

$$
\begin{aligned}
\boldsymbol{T} & =\Phi_{a} \boldsymbol{T}_{0} \boldsymbol{R}_{\theta} \\
& =\Phi_{b} \boldsymbol{T}_{0} \boldsymbol{R}_{\theta}{ }^{T}
\end{aligned}
$$

ここに,

$$
\boldsymbol{R}_{\theta}=\left[\begin{array}{ccc}
1 & 0 & 0 \\
0 & \cos \theta & -\sin \theta \\
0 & \sin \theta & \cos \theta
\end{array}\right]
$$

\section{（2）部材端変位}

変形後の部材座標系で表わされた材端変位 $\boldsymbol{d}^{*}$

$$
\begin{array}{r}
\boldsymbol{d}^{*}=\left\{u_{a}^{*}, v_{a}^{*}, w_{a}{ }^{*}, \theta_{a}^{*},\left(w_{a}^{*}\right)^{\prime},\left(v_{a}^{*}\right)^{\prime},\right. \\
\left.u_{b}{ }^{*}, v_{b}{ }^{*}, w_{b}{ }^{*}, \theta_{b}{ }^{*},\left(w_{b}^{*}\right)^{\prime},\left(v_{b}^{*}\right)^{\prime}\right\}^{T}
\end{array}
$$

の各成分は次のようになる.ここに, プライムは $x$ に関 する微分を表わす.

変位量については

$$
\left.\begin{array}{l}
u_{b}^{*}-u_{a}^{*}=\Delta l \\
v_{a}^{*}=w_{a}^{*}=v_{b}^{*}=w_{b}^{*}=0
\end{array}\right\}
$$

ここに, $\Delta l$ は部材の伸びである.

回転量については, 定義

$$
\left(w_{a}^{*}\right)^{\prime}=-\left.\frac{\partial w^{*}}{\partial x}\right|_{a},\left(v_{a}^{*}\right)^{\prime}=\left.\frac{\partial v^{*}}{\partial x}\right|_{a}, \text { etc. }
$$

より, $a, b$ 両端における重心軸の接線ベクトル $\boldsymbol{x}_{a}{ }^{*}, \boldsymbol{x}_{b}{ }^{*}$ の変形後の座標系に対する方向余弦

$$
\left.\begin{array}{l}
\left(l_{a}, m_{a}, n_{a}\right)^{T}=\boldsymbol{T}^{T} \boldsymbol{x}_{a}{ }^{*} \\
\left(l_{b}, m_{b}, n_{b}\right)^{T}=\boldsymbol{T}^{T} \boldsymbol{x}_{b}{ }^{*}
\end{array}\right\}
$$

を用いて，次式のように表わせる。

$$
\left.\begin{array}{l}
\left(w_{a}^{*}\right)^{\prime}=-n_{a} / l_{a} \\
\left(v_{a}^{*}\right)^{\prime}=m_{a} / l_{a} \\
\left(w_{b} *\right)^{\prime}=-n_{b} / l_{b} \\
\left(v_{b}^{*}\right)^{\prime}=m_{b} / l_{b} \\
-\theta_{a}{ }^{*}=\theta_{b}{ }^{*}=\phi / 2
\end{array}\right\}
$$

\section{4. 剛性 行 列}

本文で用いた剛性行列の誘導過程を簡単に説明す

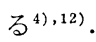

\section{(1) 誘導仮 定}

空間骨組部材の幾何学的剛性行列を求めるときに, 次 の仮定を設けた。

1）部材は等断面直線材で，断面は 2 軸対称である.

2) 断面形状は不変である.

3）部材のひずみは小さくて，ひずみと応力の関係は 線形である.

4）曲げによるせん断変形と曲げねじりの影響は無視 する。

部材座標は, $x$ 軸を重心軸に, $y, z$ 軸を断面の主軸方 向に一致させ，これらは直交右手系をなすものとする.

これらの部材軸方向の変位成分を $u, v, v$ とし, 点 $(x$, $y, z)$ に扔けるひずみ成分には次式に示すむのを用いた.

$$
\begin{aligned}
& \varepsilon_{x}=\frac{\partial u}{\partial x}+\frac{1}{2}\left(\frac{\partial v}{\partial x}\right)^{2}+\frac{1}{2}\left(\frac{\partial w}{\partial x}\right)^{2} \\
& \gamma_{x y}=\frac{\partial v}{\partial x}+\frac{\partial u}{\partial y} \\
& \gamma_{z x}=\frac{\partial u}{\partial z}+\frac{\partial w}{\partial x} \\
& \varepsilon_{y}=\varepsilon_{z}=i y z=0
\end{aligned}
$$

重心軸上の $x, y, z$ 方向の变位成分を $u_{0}, \tau_{0}, w_{0}$ と し, $x$ 軸まわりの回転を $\phi_{0}$, そりを $\omega$ とすると, 断面 上の点 $(x, y, z)$ の変位は断面の回転を微小とすれば,

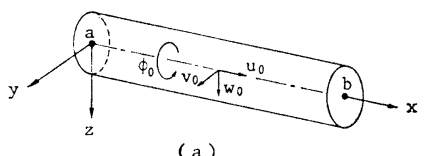

(a)

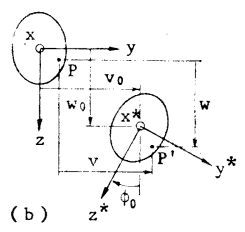

Fig. 4 Displacements of member 
次のように表わせる注).

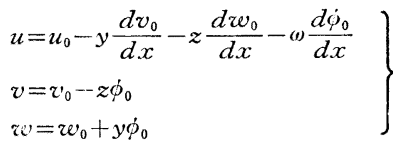

\section{（2）エネルギー原理に基づく定式化}

变形前の座標系で表わした部材両端 $a, b$ の変位を

$$
\begin{array}{r}
\boldsymbol{d}=\left(u_{a}, v_{a}, w_{a}, \theta_{a}, w_{a}{ }^{\prime}, v_{a}{ }^{\prime}, u_{b}, v_{b},\right. \\
\left.w_{b}, \theta_{b}, w_{b^{\prime}}, v_{b}\right)^{T} \ldots \ldots \ldots . .
\end{array}
$$

とし, 重心点の変位を

$$
\boldsymbol{d}_{0}=\left(u_{0}, v_{0}, w_{0}, \phi_{0}\right)^{T}
$$

とおく.

$$
\begin{aligned}
& \text { パラメーター } \boldsymbol{\alpha} \\
& \quad \boldsymbol{\alpha}=\left(\alpha_{1}, \alpha_{2}, \cdots, \alpha_{12}\right)^{T}
\end{aligned}
$$

を用いて， $\boldsymbol{d}_{0}$ を $x$ に関するべき級数で仮定する.

$$
d_{0}=M a
$$

ここに,

$$
\boldsymbol{M}=\left[\begin{array}{cccccccccccc}
1 & x & 0 & 0 & 0 & 0 & 0 & 0 & 0 & 0 & 0 & 0 \\
0 & 0 & 1 & x & x^{2} & x^{3} & 0 & 0 & 0 & 0 & 0 & 0 \\
0 & 0 & 0 & 0 & 0 & 0 & 1 & x & x^{2} & x^{3} & 0 & 0 \\
0 & 0 & 0 & 0 & 0 & 0 & 0 & 0 & 0 & 0 & 1 & x
\end{array}\right]
$$

$\boldsymbol{\alpha}$ 注部材の両端での境界条件より, 材端変位 $\boldsymbol{d}$ を用 いて表わすことができる．この $\boldsymbol{\alpha}$ を式（44）に代入す れば

$$
\boldsymbol{d}_{0}=H d
$$

となる。一例として，両端岡節点の場合には

$$
\begin{aligned}
& \boldsymbol{H}=\left[\begin{array}{cccccc}
1-\xi & 0 & 0 & 0 & 0 & 0 \\
0 & 1-3 \hat{\xi}^{2}+2 \xi^{3} & 0 & 0 & 0 & l\left(\xi-2 \hat{\xi}^{2}+\xi^{3}\right) \\
0 & 0 & 1-3 \hat{\xi}^{2}+2 \xi^{3} & 0-l\left(\xi-2 \xi^{2}+\xi^{3}\right) & 0 \\
0 & 0 & 0 & 1-\hat{\xi} & 0 & 0
\end{array}\right. \\
& \left.\begin{array}{cccccc}
\xi & 0 & 0 & 0 & 0 & 0 \\
0 & 3 \xi^{2}-2 \xi^{3} & 0 & 0 & 0 & -l\left(\xi^{2}-\xi^{3}\right) \\
0 & 0 & 3 \xi^{2}-2 \xi^{3} & 0 & l\left(\xi^{2}-\xi^{3}\right) & 0 \\
0 & 0 & 0 & \xi & 0 & 0
\end{array}\right]
\end{aligned}
$$

ここに, lは部材長であり,$\xi=x / l$ である。

部材のひずみエネルギーは

$$
U=\frac{E}{2} \int_{V} x^{2} d V+\frac{G}{2} \int_{V}\left(\gamma x y^{2}+\gamma_{z} x^{2}\right) d V
$$

またひずみは式（39），(40)より

$$
\begin{aligned}
& \varepsilon_{x}=u_{0}{ }^{\prime}-v_{0}^{\prime \prime} y-w_{0}^{\prime \prime} Z+\frac{1}{2}\left(v_{0}^{\prime}\right)^{2}+\frac{1}{2}\left(w_{0}^{\prime}\right)^{2} \\
& -\dot{\rho}_{0}^{\prime}\left(v_{0}^{\prime} z-w_{0}^{\prime} y\right)+\frac{1}{2}\left(\dot{\varphi}_{0}^{\prime}\right)^{2}\left(y^{2}+z^{2}\right) \\
& \gamma_{x y}=-\dot{\varphi}_{0}{ }^{\prime} z-\dot{\phi}_{0}{ }^{\prime} \frac{\partial \omega}{\partial y} \\
& \check{i}_{z x}=\phi_{0}^{\prime} y-\phi_{0}{ }^{\prime} \frac{\partial \omega}{\partial z}
\end{aligned}
$$

注）仮定より部材のひずタは小出いとしているので，回服に よる项は線形項のみを用いた．回転记上る高次の項を考 虏した式は，後の考察で説明する。
となるからこれらを式（48）に代入すれば

$$
\begin{aligned}
& U=\frac{E A}{2} \int_{0}^{l}\left[\left(u_{0}^{\prime}\right)^{2}+u_{0}^{\prime}\left\{\left(v_{0}^{\prime}\right)^{2}+\left(w_{0}^{\prime}\right)^{2}\right\}\right. \\
& \left.+\frac{1}{4}\left\{\left(v_{0}{ }^{\prime}\right)^{2}+\left(w_{0}\right)^{2}\right\}^{2}\right] d x \\
& +\frac{E I_{z}}{2} \int_{0}^{l}\left[\left(v_{0}^{\prime \prime}\right)^{2}+u_{0}{ }^{\prime}\left(\dot{\phi}_{0}{ }^{\prime}\right)^{2}-2 v_{0}^{\prime \prime} w_{0}^{\prime} \dot{\phi}_{0}^{\prime}\right. \\
& \left.+\frac{1}{2}\left\{\left(v_{0}^{\prime}\right)^{2}+3\left(w_{0}^{\prime}\right)^{2}\right\}\left(\phi_{0}^{\prime}\right)^{2}\right] d x \\
& +\frac{E I_{y}}{2} \int_{0}^{l}\left[\left(w_{0}^{\prime \prime}\right)^{2}+u_{0}{ }^{\prime}\left(\dot{\phi}_{0}^{\prime}\right)^{2}+2 v_{0}^{\prime} w_{0}^{\prime \prime} \dot{\phi}_{0}^{\prime}\right. \\
& \left.+\frac{1}{2}\left\{3\left(v_{0}^{\prime}\right)^{2}+\left(w_{0}^{\prime}\right)^{2}\right\}\left(\dot{\varphi}_{0}^{\prime}\right)^{2}\right] d x \\
& +\frac{G J}{2} \int_{0}^{l}\left(\phi_{0^{\prime}}\right)^{2} d x+\frac{E I_{r}}{8} \int_{0}^{l}\left(\dot{\phi}_{0^{\prime}}\right)^{4} d x
\end{aligned}
$$

ここに，

$$
\left.\begin{array}{l}
A=\int_{A} d A, I_{y}=\int_{A} z^{2} d A, I_{z}=\int_{A} y^{2} d A \\
J=\int_{A}\left\{\left(z+\frac{\partial \omega}{\partial y}\right)^{2}+\left(y-\frac{\partial \omega}{\partial z}\right)^{2}\right\} d A \\
I_{r}=\int_{A}\left(y^{2}+z^{2}\right)^{2} d A
\end{array}\right\}
$$

式（52）の下線をほどこした項は，高次の微少項とし て省略できる.

部材端力 $\boldsymbol{f}$ と材端変位 $\boldsymbol{d}$ との関係式は, 式 (52) に 式 (46) を代入し，エネルギー原理から剛性行列 $k$ を用 いて次式のような形に導くことができる。

$$
\boldsymbol{f}=\boldsymbol{k}(\boldsymbol{d}) \cdot \boldsymbol{d}=\left\{\boldsymbol{k}_{0}+\boldsymbol{k}_{1}(\boldsymbol{d})+\boldsymbol{k}_{2}(\boldsymbol{d})\right\} \mathrm{d}
$$

上式において， $k_{0}$ 注線形項であり， $k_{1} ， k_{2}$ 法それぞ れ変位 $\boldsymbol{d}$ の 1 次および 2 次の項を含む非線形項である. また，増分量に関する式は，次のようになる。

$$
\Delta \boldsymbol{f}=\boldsymbol{\Delta} \boldsymbol{k}(\boldsymbol{d}) \cdot \boldsymbol{\Delta d}=\left\{\boldsymbol{k}_{0}+2 \boldsymbol{k}_{1}(\boldsymbol{d})+3 \boldsymbol{k}_{2}(\boldsymbol{d})\right\} \boldsymbol{\Delta d} \cdots(55)
$$

用性行列 $\boldsymbol{k}$ 在, 両端剛節点の場合について付録 1 に 示した.［］でくくった項は, 式(52)の下線をほどこし た項に対応寸る. なお, 数值計算においては, 式 (54), (55) の岡性行列に含まれる材端変位 $\boldsymbol{d}$ には, 変形後の 座標系で表わされた式（34）の变拉 $\boldsymbol{d}^{*}$ 妾用いなければ ならない.

\section{5. 数値計算例}

\section{（1） 解 法}

本文で示した式 (15),(32),(34) 上前述の文献2) 5) に 示された式を比較するために数值計算を行った。剛性行 列は文献 4) では具体的に示されておらず，その他の文 献 (2),31,5亿示された式は大変位問題には適用しがたいと 思われるので, 本文で導いた式を用いた.このとき, 式 (52) の最後の積分項は省略した，座標変換と材端変位 に関寸る式の違いを調べるために, 次の 3 つの解法を用 いた. 
解法 1 は本文で示した式を用いたものであり, 解法 2 はOran が示した文献 5) の式 (2)〜（11）を用いたもの である.

解法 3 は，文献2) 4) 亿示された式拉よび考え方を用い て，次のように一部修正した解法である。すなわち，変 形後の部材の両端 $a, b$ を通るよらに $x$ 軸をとり, 部材 の回転角からコード・アングルを修正して変形後の座標 系を求めることはこれらの文献の解法と同じであるが, 回転角は文献 4)の考え方により，部材雨端の称じり角が $\theta_{a}{ }^{*}=-\theta_{b}{ }^{*}$ となるように決めた注)，材端変位から剛体 変位㧍よび回転を除くには，文献 2)の式を用いた。回転 行列, 座標変換行列および材端変位以外の計算式と計算 手法は，すべての解法において同じである.

非線形方程式の解法には, Newton-Raphson 法と荷 重増分法を併用した．このとき，解の収束性を良くする ために推定増分法 ${ }^{13)}$ を用いた。推定増分法とは，荷重を 1 2 回增分した後, 新たな荷重増分に対する変位増分 の第 1 近似值を前段階までの計算結果から外插的に推定 する方法である. 本文では, 推定值の計算には 2 次の曲 線式を用いた。

\section{（2）計 算 例}

数值計算例として, 図一 5 に示すような放物線固定ア 一于の面外座屈後の大変位問題を扱う。面内荷重として 全載等分布荷重 $p$ をアーチの面外弾性座屈荷重の 2 倍 まで載荷した。このとき, 面外変形が生じるように, 初 期荷重として等分布水平荷重 $q$ をアーチの全長にわたっ て作用させた．計算に用いた数值は次のとおりである.

$$
\begin{aligned}
& E A=0.4 \times 10^{7}, E I_{y}=0.1 \times 10^{7}, E I_{z}=0.1 \times 10^{6} \\
& G J=0.1 \times 10^{6}, p=r p_{c r}, r=0.0 \sim 2.0, p_{c r}=3.880 \\
& q / p_{c r}=1 / 10000,1 / 100,1 / 10
\end{aligned}
$$

ここに, $E I_{y}$ は面内, $E I_{z}$ は面外曲げ剛性である. $p_{c r}$ は面外弹性座屈荷重であり, 固有值問題に対する解とし て求めた. 計算においては, アーチリブを 20 分割した.

計算結果の一部を, 図一6〜10 に示した. 初期荷重が $q=p_{c r} / 10000$ の場合には, 計算値は分岐座屈の性状を よく表わしている（図一6〜9）.

解法の比較については, 両内荷重が座屈荷重より小さ

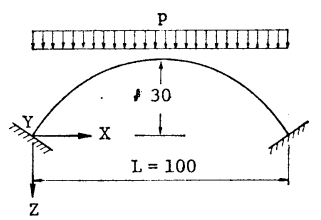

Fig. 5 Numerical example

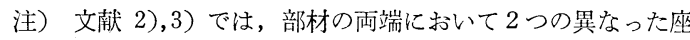
標変換行列を用いているが，上記の仮定により，この 2 つの行列は同一のものになる.

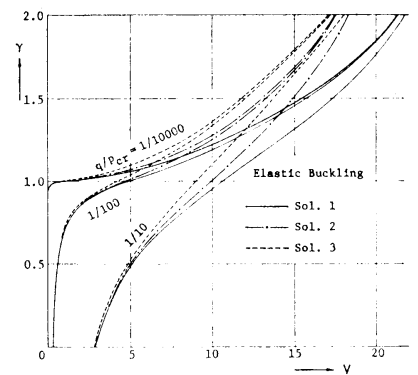

Fig. 6 Displacement at crown of arch in $Y$-direction

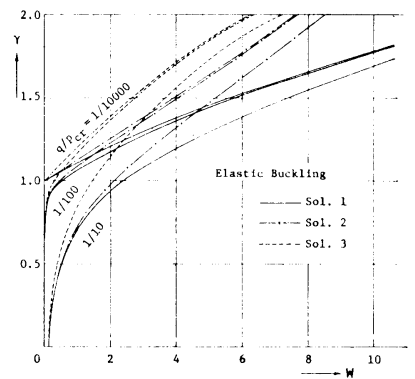

Fig. 7 Displacement at crown of arch in Z-direction

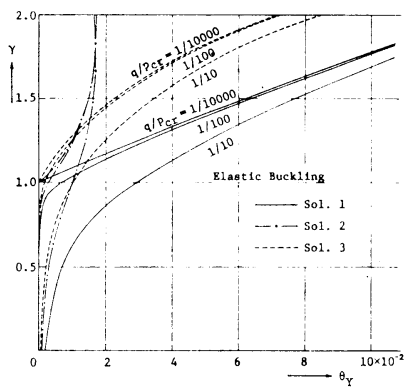

Fig. 8 Joint rotation angle at $L / 4$ of arch about $Y$-axis

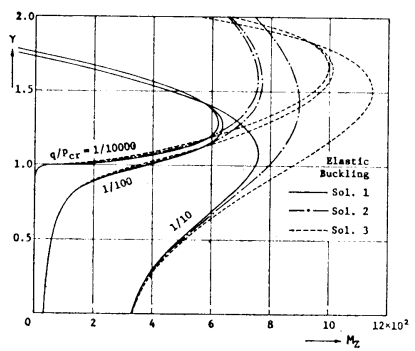

Fig. 9 Fixed-end moment about $Z$-axis

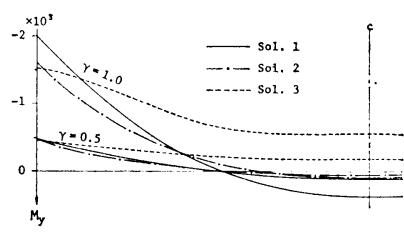

Fig. 10 Bending moment at arch rib about $y$-axis $\left(q / p_{c r}=1 / 10\right)$ 


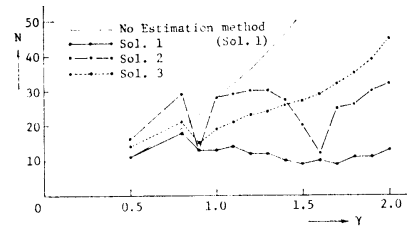

Fig. 11 Iterative numbers of Newton-Raphson method $\left(q / p_{c r}=1 / 10\right)$

い場合（ $r<1.0 ）$ にはその差はわずかであるが， $r>$ 1.0 の場合には変位, 曲げモーメントともに著しい差が 恋められる. また,面外方向の初期荷重が大きくなると， 座屈荷重以下のときにも解法による差が現われる（図一 8, 10). したがって, 回転角が大きくなる場合には, 従

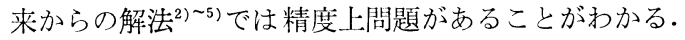

解の収束性を比較するために, Newton-Raphson 法 の反復回数を調べた. 収束性を反復回数の総数で表わす 上, 解法 1 に比べて解法 2 では約 2 3 倍, 解法 3 では 2〜4 倍になった. したがって, 解法 1 は他の解法に比 べて計算時間が $1 / 4 \sim 1 / 2$ であり，極めて収束性が良いと いえる. $q / p_{c r}=1 / 10$ のとき, 推定増分法を用いた場合 の反復回数 $N$ を図一11に示した。 また, 解法 1 に打い て推定法を用いない場合の反復回数も併せて示した。

\section{6. 考察}

\section{（1）回転行列と回転の合成}

前述のように, 有限な回転の合成はベクトル則には徒 わないので，回転の合成には回転行列を用いなければな らないが，そのときの合成式について考察を行う。

回転行列, 式 (2) の行列式は定義より1でなければな らない. 式 (15) の回転行列は厳密な式であるので, そ の行列式は 1 である. また, 式（4）を用いて合成された 回転行列の積も正規直交行列となる.

一方，微小回転に対する式（5）または式（18）の行列 式は

$$
\operatorname{det}|\Delta \boldsymbol{R}|=1+\left(\Delta \theta_{X}{ }^{2}+\Delta \theta_{Y}{ }^{2}+\Delta \theta_{Z}{ }^{2}\right)
$$

となる.さらに, 式 (19) を用いて合成した結果は $\operatorname{det}\left|\sum \Delta \boldsymbol{R}\right|=1+\left(\sum \Delta \theta_{X}\right)^{2}+\left(\sum \mathcal{J} \theta_{Y}\right)^{2}+\left(\sum \mathcal{J} \theta_{Z}\right)^{2}$

となる. そこで, これらの計算式の精度を調べるために 数值を代入して比較する.

回転角の 3 成分が等しい場合について，第 $k$ 回目の回 転角の成分を $\theta_{k}$ とし，これを 10 回続けて回転したと きの合成結果を調べる.このとき, 回転角の増分量 $\Delta \theta$ について次の 2 通りを考えた.

a）各回の回転角を一定とする場合

$$
\theta_{k}=\theta_{k-1}(k=2,3, \cdots, 10)
$$

Table 1 Determinant and elements of composite

\begin{tabular}{|c|c|c|c|c|c|c|}
\hline & \multicolumn{2}{|c|}{ Equations } & \multicolumn{2}{|c|}{$\sum \theta_{k}=10.0^{\circ}$} & \multicolumn{2}{|c|}{$\sum \theta_{k}=15.0^{\circ}$} \\
\hline & $\boldsymbol{R}$ & $\Sigma$ & $\Delta \theta=0^{\circ}$ & $\Delta \theta=0.2^{\circ}$ & $\Delta \theta=0^{\circ}$ & $\Delta \theta=0.3^{\circ}$ \\
\hline \multirow{3}{*}{ Det. } & (15) & (4) & 1.0 & 1.0 & 1.0 & 1.0 \\
\hline & (18) & (4) & 1.0092 & 1.0122 & 1.0208 & 1.0277 \\
\hline & (18) & (19) & 1.0914 & 1.0914 & 1.2056 & 1.2056 \\
\hline \multirow{3}{*}{$r_{11}$} & (15) & (4) & 0.9698 & 0.9698 & 0.9326 & 0.9326 \\
\hline & (18) & (4) & 0.9727 & 0.9737 & 0.9389 & 0.9410 \\
\hline & (18) & (19) & 1.0 & 1.0 & 1.0 & 1.0 \\
\hline \multirow{3}{*}{$r_{12}$} & (15) & (4) & -0.1568 & -0.1568 & -0.2192 & -0.2192 \\
\hline & (18) & (4) & -0.1590 & -0.1597 & -0.2248 & -0.2266 \\
\hline & (18) & (19) & -0.1745 & -0.1745 & -0.2618 & -0.2618 \\
\hline \multirow{3}{*}{$r_{13}$} & (15) & (4) & 0.1870 & 0.1870 & 0.2866 & 0.2866 \\
\hline & (18) & (4) & 0.1863 & 0.1860 & 0.2859 & 0.2855 \\
\hline & (18) & (19) & 0.1745 & 0.1745 & 0.2618 & 0.2618 \\
\hline
\end{tabular}
rotation matrix

b) 各回の回転角を一定の増分量で増加させる場合 $\theta_{k}=\theta_{k-1}+\Delta \theta(k=2,3, \cdots, 10)$

回転角の 3 成分が等しい場合には，あとで説明するよ うに合成された回転行列の要素には次の関係が成立つ。

$$
r_{11}=r_{22}=r_{33}, r_{12}=r_{23}=r_{31}, r_{13}=r_{21}=r_{32}
$$

表一1に合成された回転行列の行列式と各要素の值を 示した，表より，式（18）と（19）を用いて回転をべク トル的に扱った場合の䛊差は，行列式で約 $9 \%$ と $20 \%$ ， $r_{12}$ 要素で $11 \%$ と $19 \%$ になることがわかる.しかし， 回転行列に微小回転に詨する式 (18) を用いても, 式 (4) により合成時において高次の微小項を省略しなければ， そのときの誤差は 1/5 1/10 に減少している. 一方, 式 （15）と（4）を用いた㛜密な值の場合には，a）と b）の 值が一致しているが，これは次の理由による.

回転角の 3 成分が等しい場合, 回転角の合成量 $\alpha_{k}$ は 式 (8)より

$$
\alpha_{k}=\sqrt{3} \theta_{k}
$$

となる。この $\alpha_{k}$ を用いれば, 式 (4) による合成結果は 次式のようになる.

$$
\begin{aligned}
I_{k=1}^{n} \boldsymbol{R}_{k}= & \boldsymbol{E} \cos \left(\sum_{k}^{n} \alpha_{k}\right)+\left\{1-\cos \left(\sum_{k}^{n} \alpha_{k}\right)\right\} \boldsymbol{e}_{3} \boldsymbol{e}_{3} \\
& +\boldsymbol{e}_{3} \times \boldsymbol{E} \sin \left(\sum_{k}^{n} \alpha_{k}\right) \ldots \ldots \ldots \ldots \ldots \ldots \ldots \ldots \ldots \ldots \ldots \ldots \ldots \ldots \ldots
\end{aligned}
$$

特に, 各回の回転角が一定な a) 場合には, $\alpha_{k} \equiv \alpha$ と 打くと注)

$$
\begin{aligned}
I_{k=1}^{n} \boldsymbol{R}_{k}=\boldsymbol{R}^{n}=\boldsymbol{E} \cos (n \alpha) & +\{1-\cos (n \alpha)\} \boldsymbol{e}_{3} \boldsymbol{e}_{3} \\
& +\boldsymbol{e}_{3} \times \boldsymbol{E} \sin (n \alpha) \ldots \ldots
\end{aligned}
$$

したがって，笪密な式を用いれば a）と b）の合成結 果は同一な回転となる.また, 式 (59) より式 (58) の 関係式が成り立つことは容易にわかる.

アーチの計算例において節点の回転角の合成量を調べ

注）式 (60) は回転角の 3 成分が異なる場合でも, 各回の回転 量が一定ならば成り立つ。 
ると, $q / p_{c r}=1 / 10$ の場合, $r=1.0$ で約 $10^{\circ}, r=2.0$ で 約 $30^{\circ}$ であった. したがって, 解法 2,3 では回転の合 成だけで 10〜20\% の誤差が生じていると思われる.

表一1 の計算結果は回転角の 3 成分が等しい特別な場 合であり，一般的な場合には近似式を用いると計算誤差 はさらに大きくなるが，各回の回転量が大きくならない よらに荷重増分量を小さくし，かつ式 (4)により回転の 合成を行えば，微小回転に対する国転行列を用いても計 算精度を上げることができる.

\section{（2）座標変換とたわみ角}

数值計算に用いた各種の座標変换式を部材端のたわみ 角表示式について考察する。

計算例として長さ 5 の片持ばりを考え，その変形前の 部材座標は全体座標と一致しているものとする，そし $\tau$, 固定端 $a$ 側に節点 $i$, 自由端 $b$ 側に節点 $j$ がある ものとし，この節点 $j$ を平行移動または回転させた場 合に生じるねじり角とたわみ角および変形後の座標変換 行列について調べる. 式 (34) の材端変位のなかで，平 行移動に関する成分はいずれの解法においても式 (35) が成立するので問題は京い。

a) 平行移動のみの場合

断面の主軸 $y, z$ 方向に節点 $j$ をそれぞれ 1 だけ平行 移動させる.このとき，いずれの解法においても次式が 成立する.

$$
\theta_{a}^{*}=\theta_{b}^{*}=0,\left(\tau_{a}^{*}\right)^{\prime}=-\left(v_{a}^{*}\right)^{\prime}=\left(w_{b}^{*}\right)^{\prime}=-\left(v_{b}{ }^{*}\right)^{\prime} \equiv \tau
$$

たわみ角 $\tau$ の值は, 解法 1 では 0.2 であるのに対し て, 解法 2,3 ではともに 0.19245 となる. この違い は, 解法 2 では図一2の $\alpha_{a}, \alpha_{b}$ を無視して, $\cos \alpha_{a}=$ $\cos \alpha_{b} \fallingdotseq 1$ としているために

$$
\left(w_{a}^{*}\right)^{\prime}=\left(w_{b}-w_{a}\right) / L,\left(v_{a}^{*}\right)^{\prime}=-\left(v_{b}-v_{a}^{\prime}\right) / L \text { etc. }
$$

となる．ここに，Lは変形後の部材長である．解法 3 で は節点回転角が 0 であるので，たわみ角は部材回転角に 等しくなる、したがって, 式 (62) が成り立つ注).

ゆえに，両者の解法では平行移動のみを与えた場合， たわみ角は変形前の座標系で表わされていることにな る. 一方, 解法 1 では, たわみ角は变形後の $x$ 軸の方向 余弦を用いて式 (38) で与えられるから，たわみ角は変 形後の座標系で表わされている.

変形後の座標変換行列については, 解法 2 では原論 文5)の式 $(9) \sim(11)$ より行列の要素 $r_{23}$ と $r_{32}$ が 0 に なる.しかし，節点移動により断面主軸は 2 軸まわりの 回転を行うために, 上述の要素は 0 にはならない.さら

注） Tezcan の原論文2)では, 部材回転角の arcsine を用いて いるので,この埸合には $\tau \fallingdotseq 0.19366$ となる.
に, 原式 (11) で与えられている変換行列は正規直交行 列ではない. 解法 3 でも, 変形後のコード・アングルの 求め方が㛜密でないために, 変換行列の要素 $r_{23}$ が 0 に なる注).

\section{b）回転のみの場合}

節点 $j$ を全体座標軸 $X, Y, Z$ のまわりにそれぞれ $10^{\circ}$ ずつ回転させる．この場合には，変形前後の $x$ 朝が一致 するために，変形後の座標系で表わされた固定端側のた わみ角は，すべての解法において0である。

Table 2 Relative end rotations of member

\begin{tabular}{c|c|c|c}
\hline & $\theta_{b}{ }^{*}$ & $\left(w_{b}^{*}\right)^{\prime}$ & $\left(v_{b}\right)^{\prime}$ \\
\hline Linear & 0.17453 & 0.17453 & 0.17453 \\
\hline Sol. 1 & 0.08771 & 0.17793 & 0.17793 \\
Sol. 2 & 0.08727 & 0.17453 & 0.17453 \\
Sol. 3 & 0.08727 & 0.18908 & 0.15866 \\
\hline
\end{tabular}

自由端 $b$ における部材のねじり角とたわみ角を表一2 に示した. 权じり角は, 解法 2,3 とも相対称じり角 $\phi$ $\left(=2 \theta_{b}^{*}\right)$ の值が線形解に一致している. しかし, 厳密 には 3 軸まわりの回転の連成効果により, 線形解には一 致しない.たわみ角は, 解法 2 では微小回䎐の回転行列 を用いているために線形解と同じ值になる. 解法 3 で は, 変形後の座標変換行列には $\theta_{Y}, \theta_{Z}$ が影響しないの で, 変換行列は変形前の部材軸回りの平面的な回転を表 わすことになる.すなわち， 2 主軸回りの回転による端 面の傾きを無視していることから，2つのたわみ角の值 は一致していない.

座標変換行列については, 解法 3 では上述のような問 題点があり, 解法 2 では部材再端における断面主軸の方 向余弦の算術平均を用いているために, 変換行列の要素 の值が 1 を越える矛盾が生じている.

c）平行移動と回転の場合

平行移動上回転が同時に起きる場合には，これらが独 立に起きる場合よりも解法 2,3 の精度が悪くなる.

一例として，前述の a) と b) を同時に行った場合の 計算例を示す.訃算では, 1 回の移動量を 0.1 , 回転量 を $1^{\circ}$ とし、これを 10 回引続いて行った. 自由端にお ける 10 回目の総礼じり角と総たわみ角を表一3に示す. また, 解法 2 と 3 による各回の值を解法 1 による值に対

Table 3 Relative end rotations of member

\begin{tabular}{c|c|c|c}
\hline & $\theta_{b}{ }^{*}$ & $\left(w_{b}{ }^{*}\right)^{\prime}$ & $\left(v_{b}{ }^{*}\right)^{\prime}$ \\
\hline Linear & 0.17453 & 0.17453 & 0.17453 \\
\hline Sol. 1 & 0.10480 & 0.36430 & -0.03853 \\
Sol. 2 & 0.08727 & 0.32681 & -0.05809 \\
Sol. 3 & 0.11756 & 0.34225 & -0.07556 \\
\hline
\end{tabular}

注） 原訜文 ${ }^{2), 3)}$ では, 部材の $a$ 端と $b$ 端とで異なった座標変換 行列を用いているが，いまの場合には柿じり角が 0 であ るので，2つの変換行列は一致する. 


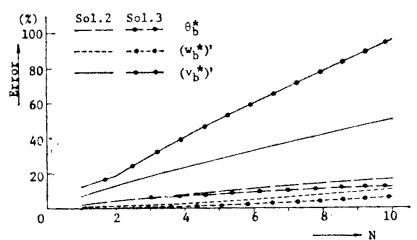

Fig. 12 Error of relative end rotations of member

する相対誤差で表わし，この絶対值を図一12 に示した.

解法 3 による $\left(v_{b}^{*}\right)^{\prime}$ の誤差が，a）と b ) の場合には それぞれ約 $4 \%$ と 10\% であったのが，表一3 では $96 \%$ になっている．この誤差は, 図一12 で第 1 回目のとき 不連続になっているが，この解法ではコード・アングル を修正することにより変形後の座標系を求めているため に, 第 1 回目は線形解のコード・アングルを用いるので 不連続になる注)。

以上の考察により, 解法 2,3 とも変形後の座標およ びその座標系で表示されたたわみ角は厳密なものではな く, 有限変位問題ではかなりの誤差が生じることがわか る.計算例では 1 端を固定したが，両端で移動と回転が 生じて剛体回転を伴う一般的な場合には，近似式による 誤差はさらに大きくなる.

\section{（3）剛性行列}

式 (54) で与えた剛性行列の性質を調べるために, 前 述のアーチについて若干の計算を行った.

まず，解法 1 において式 (54)，(55）の 2 次の非線形 項 $k_{2}$ を省略した場合, $q / p_{c r}=1 / 10000$ のときには $r=$ 0.99 までは収束したが, 弾性座屈荷重のとき（ $r=1.0 ）$ には解は収束しなかった. $q / p_{c r}=1 / 10$ のとには, $r=$ 0.5 で急に収束性が悪くなり，Newton-Raphson 法の 反復回数は $\boldsymbol{k}_{2}$ を省略しない場合の約 5 倍になった．こ のときの解の䛊差 ( $\boldsymbol{k}_{2}$ を省略しない場合の值との差) は 3〜7\% であった。ささら荷重を増加させると, 解は収 束しなかった.

次に, $\boldsymbol{k}_{2}$ の要素のなかで, 式 (52) のひずみエネル ギー $(E A / 8) \int_{0}^{l}\left\{\left(v_{0}\right)^{2}+\left(w_{0}{ }^{\prime}\right)^{2}\right\}^{2} d x$ から導かれる項を 残し, 残りの曲げ剛性 $E I_{y}, E I_{z}$ を含む項を省略した場 合には, $q / p_{c r}=1 / 10$ のと， $r=1.0$ においてすべての 変位と断面力の誤差は $1 \%$ 以下であり, $r=2.0$ では変 位で 1 2\%, 曲げモーメントで 2 4\% の誤差が生じ た.

以上の数值計算の結果から, 式 (52) のひずみエネル ギーの表示式に含まれている変位の 4 次項のうち, ねじ り率の 2 乗を含む 4 次項, すなわち下線をほどこした項

注）座標系が定まらなければ, 変形後のコード・フングルを 求めることができない矛盾がある.
は省略できるが，すべての 4 次項を省略することはでき ないといえる.

\section{（4）有限な回転場における変位}

前項で考察した剛性行列は式 (40) の変位から導かれ たものであり，この式は部材断面の回転が微小として表 わされたものである. そこで, 有限な回転場における変 位の表示式を導き, この変位を用いて誘導される剛性行 列について考察する.

図一4 において, 断面上の点 $P(x, y, z)$ の変位を求 めるために, この断面内に位置べクトル $\boldsymbol{r}(=\overrightarrow{\mathrm{OP}})$ を考 える. 断面剛の仮定により, 点 $P$ の変位を $\boldsymbol{d}$ とすれ ば，これを平行移動 $d_{1}$ と回転 $d_{2}$ とに分けることがで きる、したがって, 式 (15) の回転行列を用いれば

$$
\boldsymbol{d}=\boldsymbol{d}_{1}+\boldsymbol{d}_{2}=\boldsymbol{d}_{1}+(\boldsymbol{R}-\boldsymbol{E}) \boldsymbol{r}
$$

となる. 0 点の回転角を $\alpha$, 回転中心軸の成分を $\left(\theta_{x}\right.$, $\left.\theta_{y}, \theta_{z}\right)$ とすれば注), 変位 $\boldsymbol{d}$ の各成分は次式のようにな る.

$$
\begin{aligned}
& u=u_{0}+\left\{\frac{\theta_{x} \theta_{y}}{\alpha^{2}}(1-\cos \alpha)-\frac{\theta_{z}}{\alpha} \sin \alpha\right\} y \\
& +\left\{\frac{\theta_{x} \theta_{z}}{\alpha^{2}}(1-\cos \alpha)+\frac{\theta_{y}}{\alpha} \sin \alpha\right\} z \\
& v=v_{0}+(1-\cos \alpha)\left(\frac{\theta_{y}^{2}}{\alpha^{2}}-1\right) y \\
& +\left\{\frac{\theta_{y} \theta_{z}}{\alpha^{2}}(1-\cos \alpha)-\frac{\theta_{x}}{\alpha} \sin \alpha\right\} z \\
& \begin{array}{c}
w=w_{0}+\left\{\frac{\theta_{z} \theta_{y}}{\alpha^{2}}(1-\cos \alpha)+\frac{\theta_{x}}{\alpha} \sin \alpha\right\} y \\
+(1-\cos \alpha)\left(\frac{\theta_{z}^{2}}{\alpha^{2}}-1\right) z
\end{array}
\end{aligned}
$$

$こ こ に$

$$
a^{2}=\theta x^{2}+\theta y^{2}+\theta z^{2}
$$

式（64）が有限な回転場における有限変位を表わして いることは, ひずみと変位の関係式に代入すれば理解さ れる・すなわち，

$$
\left.\begin{array}{l}
\varepsilon_{y}=\frac{\partial v}{\partial y}+\frac{1}{2}\left\{\left(\frac{\partial u}{\partial y}\right)^{2}+\left(\frac{\partial v}{\partial y}\right)^{2}+\left(\frac{\partial w}{\partial y}\right)^{2}\right\} \\
\varepsilon_{z}=\frac{\partial w}{\partial z}+\frac{1}{2}\left\{\left(\frac{\partial u}{\partial z}\right)^{2}+\left(\frac{\partial v}{\partial z}\right)^{2}+\left(\frac{\partial w}{\partial z}\right)^{2}\right\} \\
\gamma_{y z}=\frac{\partial v}{\partial z}+\frac{\partial w}{\partial y}+\frac{\partial u}{\partial y} \frac{\partial u}{\partial z}+\frac{\partial v}{\partial y} \frac{\partial v}{\partial z}+\frac{\partial w}{\partial y} \frac{\partial w}{\partial z}
\end{array}\right\}
$$

(66.1 3)

に代入すると, 式 (39.4) の関係を満足していることが わかる.

$$
\varepsilon_{y}=\varepsilon_{z}=\gamma_{y z}=0
$$

式 (64) が従来から用いられている次式 ${ }^{4), 6), 7)}$

$$
\left.\begin{array}{r}
u=u_{0}-\left(y \cos \phi_{0}-z \sin \phi_{0}\right) v_{0}{ }^{\prime} \\
-\left(y \sin \phi_{0}+z \cos \phi_{0}\right) w_{0}{ }^{\prime} \\
v=v_{0}-z \sin \phi_{0}-y\left(1-\cos \phi_{0}\right) \\
w=w_{0}+y \sin \phi_{0}-z\left(1-\cos \phi_{0}\right)
\end{array}\right\}
$$

注） p. 14 の脚注参照 
と異なるのは注)，有限な回転を考慮したために 3 軸まわ りの回転が連成していることによる. この連成作用を無 視すれば, 式 (67) は式 (64) から導けることを示す.

まず，回転の 3 成分を次のようにおく.

$$
\left.\begin{array}{l}
\theta_{x} \doteqdot \phi_{0} \\
\theta_{y} \doteqdot \tan ^{-1}\left(-\frac{d w_{0}}{d x}\right) \doteqdot-w_{0}^{\prime} \\
\theta_{z} \doteqdot \tan ^{-1}\left(\frac{d v_{0}}{d x}\right) \doteqdot v_{0}^{\prime}
\end{array}\right\}
$$

次に，回転の連成作用を無視すれば，断面の回転中心 軸は $x$ 軸に一致するから, 式 (65) の $\alpha$ は

$$
\alpha=\dot{\phi}_{0}
$$

となる. 式 (68)，(69）を式（64.1）に代入すれば

$$
\begin{aligned}
u=u_{0} & -\left\{y\left(\frac{\sin \phi_{0}}{\phi_{0}}\right)-z\left(\frac{1-\cos \phi_{0}}{\phi_{0}}\right)\right\} v_{0}^{\prime} \\
& -\left\{y\left(\frac{1-\cos \phi_{0}}{\phi_{0}}\right)+z\left(\frac{\sin \phi_{0}}{\phi_{0}}\right)\right\} w_{0}^{\prime}
\end{aligned}
$$

ここで,

$$
\frac{\sin \phi_{0}}{\phi_{0}} \fallingdotseq \cos \dot{\phi}_{0}, \quad \frac{1-\cos \phi_{0}}{\phi_{0}} \fallingdotseq \sin \phi_{0}
$$

が成り立てば, 式 (70) は式 (67.1) に一致する. 式 (71) は $\phi_{0}$ が無限小のときに成立する.

式 $(67.2,3)$ の変位 $v, w$ は平面的な回転から導加 れた式である.すなわち，yと $z$ 軸まわりの回転による 成分を無視し, 式 (68.1) と（69）を式 $(64.2,3)$ 亿代 入すれば，式 $(67.2 ， 3)$ を得る.

以上の考察により, 式 (67) は部材の㸚じり角 $\phi_{0}$ が 微小で, かつ回転の連成効果を無視したときに導かれる 式であり，有限な回転場における変位を表わしていな い.

次に, 有限変位の近似式を求好。いま, 式 (65) の 合成回転量が小さくて $\alpha^{2} \ll 1$ と仮定することができ， かつ式 (68) が成り立つときには, これらの式を式 (64) に代入し,回転の 3 次以上の項を省略すれば次式を得る.

$$
\left.\begin{array}{l}
u=u_{0}-v_{0}{ }^{\prime} y-w_{0} z-\frac{1}{2} \phi_{0}\left(w_{0}^{\prime} y-v_{0}^{\prime} z\right) \\
v=v_{0}-\phi_{0} z-\frac{1}{2}\left\{\phi_{0}^{2} y+\left(v_{0}^{\prime}\right)^{2} y+v_{0}^{\prime} w_{0}^{\prime} z\right\} \\
w=w_{0}+\phi_{0} y-\frac{1}{2}\left\{\phi_{0}^{2} z+\left(w_{0}^{\prime}\right)^{2} z+v_{0}^{\prime} w_{0}^{\prime} y\right\}
\end{array}\right\}
$$

式（72）の非線形項を省略した式は，式（63）におい て回転行列 $\boldsymbol{R}$ に微小回転に対する式（18）を用いれば 導くことができる.この線形の式が, 式 (40) と同一の ものである. ここで, 式 (67) を級数展開しても, 式 (72) を得ることができないことには注意すべきである. 結局, 式 (66) を式 (39.4) に代入した微分方程式の 解としての変位は, 有限な回転を考虑しなければ求めら れないことが理解されよう。

注）ベルヌーイの仮定から，そりの項は省略した。

\section{（5）有限回転の影響}

式 (72) を用いて, 1 次の非線形剛性行列 $\boldsymbol{k}_{1}$ を求める. ひずみ $\varepsilon_{x}$ は, 式 (39.1) の代りに

$$
\varepsilon_{x}=\frac{\partial u}{\partial x}+\frac{1}{2}\left\{\left(\frac{\partial u}{\partial x}\right)^{2}+\left(\frac{\partial v}{\partial x}\right)^{2}+\left(\frac{\partial w}{\partial x}\right)^{2}\right\}
$$

を用いると, 3 次以上の微小項を省略して次式のように なる。

$$
\begin{aligned}
\varepsilon_{x}=u_{0}^{\prime} & -v_{0}^{\prime \prime} y-w_{0}^{\prime \prime} z+\frac{1}{2}\left\{\left(u_{0}^{\prime}\right)^{2}+\left(v_{0}^{\prime}\right)^{2}+\left(w_{0}^{\prime}\right)^{2}\right\} \\
& +\frac{1}{2}\left(v_{0}^{\prime \prime}\right)^{2} y^{2}+\frac{1}{2}\left(w_{0}^{\prime \prime}\right)^{2} z^{2} \\
& +\frac{1}{2}\left(\phi_{0}^{\prime}\right)^{2}\left(y^{2}+z^{2}\right)+v_{0}^{\prime \prime} w_{0}^{\prime \prime} y z \\
& -\frac{1}{2}\left(\phi_{0} w_{0}^{\prime \prime}-\phi_{0}^{\prime} w_{0}^{\prime}+2 u_{0}^{\prime} v_{0}^{\prime \prime}\right) y \\
& +\frac{1}{2}\left(\phi_{0} v_{0}^{\prime \prime}-\phi_{0}^{\prime} v_{0}^{\prime}-2 u_{0}^{\prime} w_{0}^{\prime \prime}\right) z \ldots \ldots \ldots . . .(7)
\end{aligned}
$$

式 (74) によるひずみエネルギーは，4 次以上の項を 省略して

$$
\begin{aligned}
& \frac{E}{2} \int_{V} \varepsilon_{x}^{2} d V=\frac{E A}{2} \int_{0}^{l}\left[\left(u_{0}{ }^{\prime}\right)^{2}+\left(u_{0}{ }^{\prime}\right)^{3}+u_{0}{ }^{\prime}\left(v_{0}\right)^{2}\right. \\
& \left.+u_{0}{ }^{\prime}\left(w_{0}^{\prime}\right)^{2}\right] d x \\
& +\frac{E I_{z}}{2} \int_{0}^{l}\left[\left(v_{0}^{\prime \prime}\right)^{2}+u_{0}{ }^{\prime}\left(\phi_{0}^{\prime}\right)^{2}+3 u_{0}{ }^{\prime}\left(v_{0}^{\prime \prime}\right)^{2}\right. \\
& \left.+\phi_{0} v_{0}^{\prime \prime} w_{0}^{\prime \prime}-\phi_{0}{ }^{\prime} v_{0}{ }^{\prime \prime} w_{0}{ }^{\prime}\right] d x \\
& +\frac{E I_{y}}{2} \int_{0}^{l}\left[\left(w_{0}^{\prime \prime}\right)^{2}+u_{0}^{\prime}\left(\phi_{0}^{\prime}\right)^{2}+3 u_{0}{ }^{\prime}\left(w_{0}^{\prime \prime}\right)^{2}\right. \\
& \left.-\phi_{0} v_{0}^{\prime \prime} w_{0}^{\prime \prime}+\phi_{0}^{\prime} v_{0}{ }^{\prime} w_{0}^{\prime \prime}\right] d x
\end{aligned}
$$

式 (75) を式 (52) と比較して新しく導かれた項を $\Delta U$ とおけば

$$
\begin{aligned}
\Delta U & =\frac{E}{2} \int_{0}^{l}\left[A\left(u_{0}^{\prime}\right)^{3}+3 I_{z} u_{0}^{\prime}\left(v_{0}^{\prime \prime}\right)^{2}\right. \\
& \left.+3 I_{y} u_{0}^{\prime}\left(w_{0}^{\prime \prime}\right)^{2}\right] d x \\
& +\frac{E}{2}\left(I_{z}-I_{y}\right) \int_{0}^{l} \phi_{0} v_{0}^{\prime \prime} w_{0}^{\prime \prime} d x \\
& +\frac{E}{2} \int_{0}^{l}\left[I_{z} \phi_{0}^{\prime} v_{0}^{\prime \prime} w_{0}^{\prime}-I_{y} \phi_{0}^{\prime} v_{0}^{\prime} w_{0}^{\prime \prime}\right] d x
\end{aligned}
$$

となる. 式 (76) の右辺第 1 項は, 式 (73) の $(\partial u / \partial x)^{2} / 2$ の項から導かれたものであり, 通常は高次の微小項とし て省略できる.

第 2 項は文献 4) でも考察されているが，この文献に 示された式では係数の值が 2 倍になっている.これは, 有限変位の表示式 (64) と（67）の相違によるものであ って, 式 (64) を級数展開した式 (72.1) の右辺第 4 項 の係数が異なるためである. また, 式 (76) の第 3 項は 式 (52)でも現われているが, 係数の違いにより式 (75) との差として求められた．変位の表示式として式 (67) を用いた場合には，たまたまひずみの式 (39.1) にお いて異符号の変位の 2 次項が現われるために, この第 3 項はひずみエネルギーには含まれなくなる ${ }^{4}$.

結局, 式 (67) を用いる限り, 最低次の非線形項を含 む剛性行列を正しく求めることができず, 有限変位解析 
としては不十分といわざるをえない。

式 (76) による剛性行列を求める.この剛性行列を $\tilde{\boldsymbol{k}}_{1}$ と書き, それぞれの項から導かれる剛性行列を $\left[d_{i}, j\right]$, $\left[e_{i, j}\right],\left[f_{i, j}\right]$ とおうけば

$$
\tilde{\boldsymbol{k}}_{\mathbf{1}}=\left[d_{i, j}\right]+\left[e_{i, j}\right]+\left[f_{i, j}\right]
$$

と書き表わすことができる. 各項の要素を 付録 2 に示 于.

式（77）による付加剛性行列の影響を，アーチの計算 例について調べてみる. 計算では，式 (54) の剛性行列 に式（77）の各項を加えた式を用いた. 剛性行列以外の 式は, 解法 1 と同じである.

初期荷重の值を $q=p_{c r} / 10$ とし, 面内荷重が $r=1.0$ と 2.0 の場合について付加剛性行列の各項の影響を表一 4 に示した. 表の值は，付加剛性を含まない場合の值に 対する相対誤差で表わした，なお， $V$ は面外変位，W はたわみ， $N$ は軸力， $M$ は部材軸まわりの曲げモーメ ントであり，それぞれの絶対值最大の值を示した。

Table 4 Relative errors of calculated values (\%)

\begin{tabular}{r|r|r|r|r|r|r}
\hline$r$ & \multicolumn{2}{|c|}{$\left[d_{i j}\right]$} & \multicolumn{2}{c|}{$\left[e_{i j}\right]$} & \multicolumn{2}{c}{$\left[f_{i j}\right]$} \\
\cline { 2 - 7 } & 1.0 & 2.0 & 1.0 & 2.0 & 1.0 & 2.0 \\
\hline$V$ & 0.3 & 0.4 & 4.1 & 3.1 & 1.2 & 1.9 \\
$W$ & 0.6 & 1.5 & 9.4 & 20.8 & 2.4 & 3.0 \\
$N$ & -0.1 & -0.4 & 0.2 & 6.0 & -1.2 & -9.3 \\
$M_{x}$ & 0.6 & 1.4 & 42.8 & 43.0 & 3.5 & 8.2 \\
$M_{y}$ & 0.4 & 0.6 & 1.1 & -5.3 & 1.8 & 3.7 \\
$M_{z}$ & 0.1 & 0.5 & 3.6 & 23.7 & 3.2 & 7.0 \\
\hline
\end{tabular}

表一4の結果より，ひずみと変位の関係式における軸 方向変位の微係数の 2 次項について, $(\partial u / \partial x)$ の 2 次項 は高次の微小項として無視できるが, 他の微係数 $(\partial u)$ $\partial y),(\partial u / \partial z)$ の 2 次項は, 3 次元の有限変位解析では省 略することができないと考えられる.

\section{7. 結語}

立体骨組構造物の幾何学的非線形問題を扱った研究の なかから,有限変位をなるべく厳密に扱った研究を選び， 本文で示した解析法と比較検討を行った．その結果, 従 来の研究においては 3 次元空間における有限変位の表示 が正確でないために, 有限変位解析としては次の諸点で 不十分であることが明らかになった。

（1）回転が微小回転として扱われており，3次元の 有限変位場における有限な回転に対する認識が欠けてい る.

（2）そのために，変位関数に含まれるべき最低次の 非線形項の一部が失われており, 有限変位解析として不 十分である。

（3）以上のことから, 構造解析における 3 つの基本
式, すなわち応力と変位の関係式, 適合条件式, 平衡条 件式のすべてが厳密には満足されていない.

本文の研究結果から, 立体骨組構造物の有限変位解析 について次のことが判明した。

（1） 3 次元空間においては，有限な回転をべクトル 的に报うことはできず，回転の合成には高次の微小項ま で用いなければならない。

（2）回転行列を用いて，㱛じり率一定の仮定のもと に厳密な座標変換行列と材端変位の表示式を求め, これ らの式を用いると Newton-Raphson 法の収束性が良く なることを示した。

（3）従来の文献で報告されていた変位場よりも精度 の高い有限変位場を求め, ひずみと変位の関係式におい て, 軸方向変位の微係数のすべての 2 次項を微小項とし て省略できないことを示した.

立体構造物の非線形解析においては，多次元の連立非 線形方程式を数值的に解かねばならない困難な問題があ る. このために種々の数值解法が発表されている ${ }^{14) ~ 17)}$. 元来, マトリックス解析法は電子計算機の使用を前提之 した奏用的な解法であるから，理論式がいくら峳密な式 であっても，数值計算において障害が起きるような解法 では工学的には価值がない。マトリックス法を実際の構 造物の非線形解析に応用寸るためには, 計算時間, 計算 精度, 記憶容量に対する制約条件が存在するために数值 計算のためのアルゴリズムの研究も必要であるが，本文 では省略した ${ }^{17)}$

橋梁構造物の長大化が進み，いままで近似的に扱われ てきた立体的な非線形性が無視できなくなってきてい る. 本文で報告した解析法を用いれば，このような立体 骨組構造物の弾性挙動を十分に追跡できると思われる. 実際の構造物の解析に適用した例については, 文献 18) 〜20）を参照していただきたい.

本研究は, 当時大学院生であった 中村 守君（現,本 四公団勤務）が行った研究21)をさらに発展させたもので ある. 同君ならびに, 式の変形と検算に多大の労力をわ ずらわした大学院生 森川孝義君 (現, 川崎製鉄勤務) と 中村 滋君に謝意を表する次第である.

\section{【付 録 1】}

式 (54) の剛性行列は対称行列であるので, 上三角行 列部分の要素を示す. 式中, $I_{y}+I_{z}=I_{p}$ とおいた.

(1) 線形項 : $k_{0}=\left[a_{i, j}\right]$

$$
\begin{aligned}
& a_{1,1}=-a_{1,7}=a_{7,7}=E A / l \\
& a_{2,2}=-a_{2,8}=a_{8,8}=12 E I_{z} / l^{3} \\
& a_{3,3}=-a_{3,9}=a_{9,9}=12 E I_{y} / l^{3}
\end{aligned}
$$




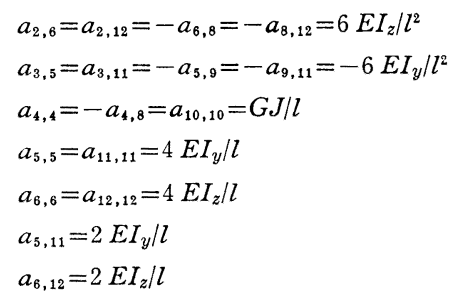

その他の要素は 0 .

（2） 1 次の非線形項 : $\boldsymbol{k}_{1}=\left[b_{i, j}\right]$

$$
\begin{aligned}
& b_{1,2}=-b_{1,8}=-b_{2,7}=b_{7,8}=\frac{3 E A}{5 l^{2}}\left(v_{b}-v_{a}\right) \\
& -\frac{E A}{20 l}\left(v_{a}^{\prime}+v_{b}^{\prime}\right) \\
& b_{1,3}=-b_{1,9}=-b_{3,7}=b_{7,9}=\frac{3 E A}{5 l^{2}}\left(w_{b}-w_{a}\right) \\
& +\frac{E A}{20 l}\left(w_{a}^{\prime}+w_{b}^{\prime}\right) \\
& b_{1,4}=-b_{1,10}=-b_{4,7}=b_{7,10}=\frac{E I_{p}}{2 l^{2}}\left(\theta_{b}-\theta_{a}\right) \\
& b_{1,5}=-b_{5,7}=-\frac{E A}{20 l}\left(w_{b}-w_{a}\right)-\frac{E A}{60}\left(4 w_{a}^{\prime}-w_{b}^{\prime}\right) \\
& b_{1,6}=-b_{6,7}=\frac{E A}{20 l}\left(v_{b}-v_{a}\right)-\frac{E A}{60}\left(4 v_{a}^{\prime}-v_{b}\right) \\
& b_{1,11}=-b_{7,11}=-\frac{E A}{20 l}\left(w_{b}-w_{a}\right)+\frac{E A}{60}\left(w_{a}^{\prime}-4 w_{b}^{\prime}\right) \\
& b_{1,12}=-b_{7,12}=\frac{E A}{20 l}\left(v_{b}-v_{a}\right)+\frac{E A}{60}\left(v_{a}^{\prime}-4 v_{b}{ }^{\prime}\right) \\
& b_{2,2}=-b_{2,8}=b_{8,8}=b_{3,3}=-b_{3,9}=b_{9,9}=\frac{3 E A}{5 l^{2}}\left(u_{b}-u_{a}\right) \\
& b_{2,4}=-b_{2,10}=-b_{4,8}=b_{8,10}=\frac{E I_{p}}{2 l^{2}}\left(w_{a}^{\prime}-w_{b}^{\prime}\right) \\
& b_{2,5}=-b_{5,8}=-b_{2,11}=b_{8,11}=b_{3,6}=-b_{6,9} \\
& =-b_{3,12}=b_{9,12}=-\frac{E I_{p}}{2 l^{2}}\left(\theta_{b}-\theta_{a}\right) \\
& b_{2,6}=-b_{6,8}=b_{2,12}=-b_{8,12}=-b_{3,5}=b_{5,9} \\
& =-b_{3,11}=b_{9,11}=\frac{E A}{20 l}\left(u_{b}-u_{a}\right) \\
& b_{3,4}=-b_{3,10}=-b_{4,9}=b_{9,10}=\frac{E I_{p}}{2 l^{2}}\left(v_{a}^{\prime}-v_{b^{\prime}}\right) \\
& b_{4,4}=-b_{4,10}=b_{10,10}=\frac{E I_{p}}{2 l^{2}}\left(u_{b}-u_{a}\right) \\
& b_{4,5}=-b_{5,10}=-\frac{E I_{p}}{2 l^{2}}\left(v_{b}-v_{a}\right)+\frac{E I_{z}}{4 l}\left(v_{a}{ }^{\prime}+v_{b}{ }^{\prime}\right) \\
& -\frac{E I_{y}}{4 l}\left(v_{a}^{\prime}-v_{b}^{\prime}\right) \\
& b_{4,6}=-b_{6,10}=-\frac{E I_{p}}{2 l^{2}}\left(w_{b}-w_{a}\right)+\frac{E I_{z}}{4 l}\left(w_{a}^{\prime}-w_{b}^{\prime}\right) \\
& -\frac{E I_{y}}{4 l}\left(w_{a}^{\prime}+w_{b}^{\prime}\right) \\
& b_{4,11}=-b_{10,11}=\frac{E I_{p}}{2 l^{2}}\left(v_{b}-v_{a}\right)-\frac{E I_{z}}{4 l}\left(v_{a}{ }^{\prime}+v_{b}{ }^{\prime}\right) \\
& -\frac{E I_{y}}{4 l}\left(v_{a}^{\prime}-v_{b}^{\prime}\right) \\
& b_{4,12}=-b_{10,12}=\frac{E I_{p}}{2 l^{2}}\left(w_{b}-w_{a}\right)+\frac{E I_{z}}{4 l}\left(w_{a}^{\prime}-w_{b}^{\prime}\right)
\end{aligned}
$$

$$
\begin{gathered}
+\frac{E I_{y}}{4 l}\left(w_{a}^{\prime}+w_{b}^{\prime}\right) \\
b_{5,5}=b_{6,6}=b_{11,11}=b_{12,12}=\frac{E A}{15}\left(u_{b}-u_{a}\right) \\
b_{5,6}=-b_{11,12}=\frac{E\left(I_{y}-I_{z}\right)}{4 l}\left(\theta_{b}-\theta_{a}\right) \\
b_{5,11}=b_{6,12}=-\frac{E A}{60}\left(u_{b}-u_{a}\right) \\
b_{5,12}=-b_{6,11}=-\frac{E I_{p}}{4 l}\left(\theta_{b}-\theta_{a}\right) \\
b_{1,1}=b_{1,7}=b_{2,3}=b_{2,9}=b_{3,8}=b_{7,7}=b_{8,9}=0
\end{gathered}
$$

\section{(3) 2 次の非線形項 : $k_{2}=\left[c_{i}, j\right]$}

式中, $I_{y}{ }^{\prime}=3 I_{y}+I_{z}, I_{z}{ }^{\prime}=I_{y}+3 I_{z}$ なる記号を用いた .

$$
\begin{aligned}
& c_{2,2}=-c_{2,3}=c_{8,8} \\
& =\frac{E A}{70 l}\left\{\frac{72}{l^{2}}\left(v_{b}-v_{a}\right)^{2}+\frac{24}{l^{2}}\left(w_{b}-w_{a}\right)^{2}\right. \\
& -\frac{18}{l}\left(v_{b}-v_{a}\right)\left(v_{a}^{\prime}+v_{b}{ }^{\prime}\right)+\frac{6}{l}\left(w_{b}-w_{a}\right)\left(w_{a}^{\prime}+w_{b}{ }^{\prime}\right) \\
& \left.+\left(w_{a}^{\prime 2}+w_{b}{ }^{2}\right)+3\left(v_{a}{ }^{2}+v_{b}{ }^{2}\right)\right\}+\left[\frac{E I_{y}{ }^{\prime}}{5 l^{3}}\left(\theta_{b}-\theta_{a}\right)^{2}\right] \\
& c_{2,3}=-c_{2,9}=-c_{3,8}=c_{8,9} \\
& =\frac{E A}{35 l}\left\{\frac{24}{l^{2}}\left(v_{b}-v_{a}\right)\left(w_{b}-w_{a}\right)\right. \\
& -\frac{3}{l}\left(w_{b}-w_{a}\right)\left(v_{a}{ }^{\prime}+v_{b}{ }^{\prime}\right)+\frac{3}{l}\left(v_{b}-v_{a}\right)\left(w_{a}^{\prime}+w_{b}{ }^{\prime}\right) \\
& \left.-\left(w_{a}^{\prime} v_{a}^{\prime}+w_{b}^{\prime} v_{b}^{\prime}\right)\right\} \\
& c_{2,4}=-c_{2,10}=-c_{4,8}=c_{8,10} \\
& =\left[\frac{E I_{y^{\prime}}}{30 l^{2}}\left\{\frac{12}{l}\left(v_{b}-v_{a}\right)-\left(v_{a}{ }^{\prime}+v_{b}^{\prime}\right)\right\}\left(\theta_{b}-\theta_{a}\right)\right] \\
& c_{2,5}=-c_{5,8}=-c_{3,6}=c_{6,9} \\
& =-\frac{E A}{420}\left\{\frac{36}{l^{2}}\left(v_{b}-v_{a}\right)\left(w_{b}-w_{a}\right)+\frac{12}{l}\left(v_{b}-v_{a}\right) w_{a}{ }^{\prime}\right. \\
& -\frac{12}{l}\left(w_{b}-w_{a}\right) v_{a}^{\prime}+w_{a}^{\prime}\left(v_{a}^{\prime}-v_{b}^{\prime}\right) \\
& \left.-w_{b}^{\prime}\left(v_{a}^{\prime}+v_{b}^{\prime}\right)\right\} \\
& c_{2,6}=-c_{6,8} \\
& =\frac{E A}{840}\left\{\frac{108}{l^{2}}\left(v_{b}-v_{a}\right)^{2}+\frac{36}{l^{2}}\left(w_{b}-w_{a}\right)^{2}\right. \\
& -\frac{72}{l}\left(v_{b}-v_{a}\right) v_{a}^{\prime}+\frac{24}{l}\left(w_{b}-w_{a}\right) w_{a}^{\prime} \\
& \left.-\left(w_{a}{ }^{\prime 2}-2 w_{a}^{\prime} w_{b}{ }^{\prime}-w_{b}{ }^{2}\right)-3\left(v_{a}{ }^{\prime 2}-2 v_{a}^{\prime} v_{b}{ }^{\prime}-v_{b}{ }^{\prime 2}\right)\right\} \\
& +\left[\frac{E I_{y^{\prime}}}{60 l^{2}}\left(\theta_{b}-\theta_{a}\right)^{2}\right] \\
& c_{2,11}=-c_{8,11}=-c_{3,12}=c_{9,12} \\
& =-\frac{E A}{420}\left\{\frac{36}{l^{2}}\left(v_{b}-v_{a}\right)\left(w_{b}-w_{a}\right)\right. \\
& +\frac{12}{l}\left(v_{b}-v_{a}\right) w_{b}^{\prime}-\frac{12}{l}\left(w_{b}-w_{a}\right) v_{b}^{\prime} \\
& \left.-w_{a}^{\prime}\left(v_{a}^{\prime}+v_{b^{\prime}}\right)-w_{b}^{\prime}\left(v_{a}^{\prime}-v_{b}^{\prime}\right)\right\} \\
& c_{2,12}=-c_{8,12} \\
& =\frac{E A}{840}\left\{\frac{108}{l^{2}}\left(v_{b}-v_{a}\right)^{2}+\frac{36}{l^{2}}\left(w_{b}-w_{a}\right)^{2}\right.
\end{aligned}
$$




$$
\begin{aligned}
& -\frac{72}{l}\left(v_{b}-v_{a}\right) v_{b}{ }^{\prime}+\frac{24}{l}\left(w_{b}-w_{a}\right) w_{b}^{\prime} \\
& +\left(w_{a}^{\prime 2}+2 w_{a}{ }^{\prime} w_{b}{ }^{\prime}-w_{b}{ }^{2}\right) \\
& \left.+3\left(v_{a}^{\prime 2}+2 v_{a}^{\prime} v_{b}^{\prime}-v_{b}^{\prime 2}\right)\right\}+\left[\frac{E I_{y}^{\prime}}{60 l^{2}}\left(\theta_{b}-\theta_{a}\right)^{2}\right] \\
& c_{3,3}=-c_{3,9}=c_{9,9} \\
& =\frac{E A}{70 l}\left\{\frac{24}{l^{2}}\left(v_{b}-v_{a}\right)^{2}+\frac{72}{l^{2}}\left(w_{b}-w_{a}\right)^{2}\right. \\
& -\frac{6}{l}\left(v_{b}-v_{a}\right)\left(v_{a}{ }^{\prime}+v_{b}^{\prime}\right)+\frac{18}{l}\left(w_{b}-w_{a}\right)\left(w_{a}{ }^{\prime}+w_{b}{ }^{\prime}\right) \\
& \left.+3\left(w_{a}{ }^{\prime 2}+w_{b}{ }^{2}\right)+\left(v_{a}{ }^{\prime 2}+v_{b}{ }^{\prime 2}\right)\right\}+\left[\frac{E I_{z}{ }^{\prime}}{5 l^{3}}\left(\theta_{b}-\theta_{a}\right)^{2}\right] \\
& c_{3,4}=-c_{3,10}=-c_{4,9}=c_{9,10} \\
& =\left[\frac{E I_{z^{\prime}}}{30 l^{2}}\left\{\frac{12}{l}\left(w_{b}-w_{a}\right)+\left(w_{a}^{\prime}+w_{b^{\prime}}\right)\right\}\left(\theta_{b}-\theta_{a}\right)\right] \\
& c_{3,5}=-c_{5,9} \\
& =-\frac{E A}{840}\left\{\frac{36}{l^{2}}\left(v_{b}-v_{a}\right)^{2}+\frac{108}{l^{2}}\left(w_{b}-w_{a}\right)^{2}\right. \\
& -\frac{24}{l}\left(v_{b}-v_{a}\right) v_{a}{ }^{\prime}+\frac{72}{l}\left(w_{b}-w_{a}^{\prime}\right) w_{a}^{\prime} \\
& -3\left(w_{a}^{\prime 2}-2 w_{a}^{\prime} w_{b}^{\prime}-w_{b}^{\prime 2}\right) \\
& \left.-\left(v_{a}^{\prime 2}-2 v_{a}^{\prime} v_{b}^{\prime}-v_{b}^{\prime 2}\right)\right\}-\left[\frac{E I_{z}^{\prime}}{60 l^{2}}\left(\theta_{b}-\theta_{a}\right)^{2}\right] \\
& c_{3,11}=-c_{9,11} \\
& =-\frac{E A}{840}\left\{\frac{36}{l^{2}}\left(v_{b}-v_{a}\right)^{2}+\frac{108}{l^{2}}\left(w_{b}-w_{a}\right)^{2}\right. \\
& -\frac{24}{l}\left(v_{b}-v_{a}\right) v_{b}^{\prime}+\frac{72}{l}\left(w_{b}-w_{a}\right) w_{b}^{\prime} \\
& +3\left(w_{a}^{\prime 2}+2 w_{a}^{\prime} w_{b}^{\prime}-w_{b}{ }^{\prime 2}\right) \\
& \left.+\left(v_{a}^{\prime 2}+2 v_{a}^{\prime} v_{b}^{\prime}-v_{b}^{\prime 2}\right)\right\}-\left[\frac{E I_{z}^{\prime}}{60 l^{2}}\left(\theta_{b}-\theta_{a}\right)^{2}\right] \\
& c_{4,4}=-c_{4,10}=c_{10,10} \\
& =\left[\frac { E I _ { y ^ { \prime } } } { 9 0 l } \left\{\frac{18}{l^{2}}\left(v_{b}-v_{a}\right)^{2}-\frac{3}{l}\left(v_{b}-v_{a}\right)\left(v_{a}^{\prime}+v_{b}{ }^{\prime}\right)\right.\right. \\
& \left.+\left(2 v_{a}^{\prime 2}-v_{a}^{\prime} v_{b}{ }^{\prime}+2 v_{b}^{\prime 2}\right)\right\} \\
& +\frac{E I_{z}{ }^{\prime}}{90 l}\left\{\frac{18}{l^{2}}\left(w_{b}-w_{a}\right)^{2}+\frac{3}{l}\left(w_{b}-w_{a}\right)\left(w_{a}^{\prime}+w_{b}{ }^{\prime}\right)\right. \\
& \left.\left.+\left(2 w_{a}^{\prime 2--} w_{a}^{\prime} w_{b}^{\prime}+2 w_{b}^{\prime 2}\right)\right\}+\frac{E I_{r}}{2 l^{3}}\left(\theta_{b}-\theta_{a}\right)^{2}\right] \\
& c_{4,5}=-c_{5,10}=\left[-\frac{E I_{z}{ }^{\prime}}{90 l}\left\{\frac{3}{l}\left(w_{b}-w_{a}\right)\right.\right. \\
& \left.\left.+\left(4 w^{\prime} a^{\prime}-w^{\prime} b^{\prime}\right)\right\}\left(\theta_{b}-\theta_{a}\right)\right] \\
& c_{4,6}=-c_{6,10}=\left[\frac { E I _ { y } { } ^ { \prime } } { 9 0 l } \left\{\frac{3}{l}\left(v_{b}-v_{a}\right)\right.\right. \\
& \left.\left.-\left(4 v_{a^{\prime}}-v_{b^{\prime}}\right)\right\}\left(\theta_{b}-0_{a}\right)\right] \\
& c_{4,11}=-c_{10,11}=\left[-\frac{E I_{z}^{\prime}}{90 l}\left\{\frac{3}{l}\left(w_{b}-w_{a}\right)\right.\right. \\
& \left.\left.-\left(w_{a}^{\prime}-4 w_{b}^{\prime}\right)\right\}\left(\theta_{b}-\theta_{a}\right)\right] \\
& c_{4,12}=-c_{10,12}=\left[\frac { E I _ { y } ^ { \prime } } { 9 0 l } \left\{\frac{3}{l}\left(v_{b}-v_{a}\right)\right.\right. \\
& \left.\left.+\left(v_{a}^{\prime}-4 v_{b}^{\prime}\right)\right\}\left(\theta_{b}-\theta_{a}\right)\right]
\end{aligned}
$$

$$
\begin{aligned}
& c_{5,5}=\frac{E A l}{1260}\left\{\frac{18}{l^{2}}\left(v_{b}-v_{a}\right)^{2}+\frac{54}{l^{2}}\left(w_{b}-w_{a}\right)^{2}\right. \\
& +\frac{3}{l}\left(v_{b}-v_{a}\right)\left(v_{a}^{\prime}-v_{b}^{\prime}\right)-\frac{9}{l}\left(w_{b}-w_{a}\right)\left(w_{a}^{\prime}-w_{b}^{\prime}\right) \\
& +3\left(12 w_{a}^{\prime 2}-9 w_{a}^{\prime} w_{b}{ }^{\prime}+w_{b}{ }^{2}\right) \\
& \left.+\left(12 v_{a}^{\prime 2}-3 v_{a}^{\prime} v_{b}{ }^{\prime}+v_{b}^{\prime 2}\right)\right\}+\left[\frac{E I_{z}^{\prime}}{45 l}\left(\theta_{b}-\theta_{a}\right)^{2}\right] \\
& c_{5,6}=-\frac{E A l}{1260}\left\{\frac{36}{l^{2}}\left(v_{b}-v_{a}\right)\left(w_{b}-w_{a}\right)\right. \\
& -\frac{3}{l}\left(v_{b}-v_{a}\right)\left(w_{a}^{\prime}-w_{b}^{\prime}\right)+\frac{3}{l}\left(w_{b}-w_{a}\right)\left(v_{a}^{\prime}-v_{b}^{\prime}\right) \\
& \left.-3 w_{a}^{\prime}\left(8 v_{a}^{\prime}-v_{b}^{\prime}\right)+w_{b^{\prime}}\left(3 v_{a}^{\prime}-2 v_{b^{\prime}}\right)\right\} \\
& c_{5,11}=-\frac{E A l}{2520}\left\{\frac{6}{l}\left(v_{b}-v_{a}\right)\left(v_{a}^{\prime}+v_{b}^{\prime}\right)\right. \\
& -\frac{18}{l}\left(w_{b}-w_{a}\right)\left(w_{a}^{\prime}+w_{b}^{\prime}\right) \\
& +3\left(3 w_{a}^{\prime 2}-4 w_{a}^{\prime} w_{b}{ }^{\prime}+3 w_{b}{ }^{2}\right) \\
& \left.+\left(3 v_{a}^{\prime 2}-4 v_{a}^{\prime} v_{b}{ }^{\prime}+3 v_{b^{\prime}}{ }^{2}\right)\right\}-\left[\frac{E I_{z}^{\prime}}{180 l}\left(\theta_{b}-\theta_{a}\right)^{2}\right] \\
& c_{5,12}=-\frac{E A l}{1260}\left\{\frac{3}{l}\left(v_{b}-v_{a}\right)\left(w_{a}^{\prime}+w_{b}^{\prime}\right)\right. \\
& -\frac{3}{l}\left(w_{b}-w_{a}\right)\left(v_{a}^{\prime}+v_{b}^{\prime}\right) \\
& \left.+w_{a}^{\prime}\left(3 v_{a}^{\prime}-2 v_{b}^{\prime}\right)-w_{b}^{\prime}\left(2 v_{a}^{\prime}-3 v_{b}^{\prime}\right)\right\} \\
& c_{6,6}=\frac{E A l}{1260}\left\{\frac{54}{l^{2}}\left(v_{b}-v_{a}\right)^{2}+\frac{18}{l^{2}}\left(w_{b}-w_{a}\right)^{2}\right. \\
& +\frac{9}{l}\left(v_{b}-v_{a}\right)\left(v_{a}^{\prime}-v_{b}{ }^{\prime}\right)-\frac{3}{l}\left(w_{b}-w_{a}\right)\left(w_{a}^{\prime}-w_{b}{ }^{\prime}\right) \\
& +\left(12 w_{a}^{\prime 2}-3 w_{a}^{\prime} w_{b}{ }^{\prime}+w_{b}{ }^{\prime 2}\right) \\
& \left.+3\left(12 v_{a}{ }^{\prime 2}-3 v_{a}{ }^{\prime} v_{b}{ }^{\prime}+v_{b}{ }^{2}\right)\right\}+\left[\frac{E I_{y}{ }^{\prime}}{45 l}\left(\theta_{b}-\theta_{a}\right)^{2}\right] \\
& c_{6,11}=-\frac{E A l}{1260}\left\{\frac{3}{l}\left(v_{b}-v_{a}\right)\left(w_{a}^{\prime}+w_{b}^{\prime}\right)\right. \\
& -\frac{3}{l}\left(w_{b}-w_{a}\right)\left(v_{a}^{\prime}+v_{b}^{\prime}\right)+w_{a}^{\prime}\left(3 v_{a}^{\prime}-2 v_{b}^{\prime}\right) \\
& \left.-w_{b}^{\prime}\left(2 v_{a}^{\prime}-3 v_{b}^{\prime}\right)\right\} \\
& c_{6,12}=-\frac{E A l}{2520}\left\{\frac{18}{l}\left(v_{b}-v_{a}\right)\left(v_{a}^{\prime}+v_{b}^{\prime}\right)\right. \\
& -\frac{6}{l}\left(w_{b}-w_{a}\right)\left(w_{a}^{\prime}+w_{b}^{\prime}\right) \\
& +\left(3 w_{a}^{\prime 2}-4 w_{a}^{\prime} w_{b}{ }^{\prime}+3 w_{b}{ }^{\prime 2}\right) \\
& \left.+3\left(3 v_{a^{\prime 2}}-4 v_{a}^{\prime} v_{b}^{\prime}+3 v_{a^{\prime 2}}{ }^{2}\right)\right\}-\left[\frac{E I_{y^{\prime}}}{180 l}\left(\theta_{b}-\theta_{a}\right)^{2}\right] \\
& c_{11,11}=\frac{E A l}{1260}\left\{\frac{18}{l^{2}}\left(v_{b}-v_{a}\right)^{2}+\frac{54}{l^{2}}\left(w_{b}-w_{a}\right)^{2}\right. \\
& -\frac{3}{l}\left(v_{b}-v_{a}\right)\left(v_{a}^{\prime}-v_{b}^{\prime}\right)+\frac{9}{l}\left(w_{b}-w_{a}\right)\left(w_{a}^{\prime}-w_{b}^{\prime}\right) \\
& +3\left(w_{a}^{\prime}{ }^{2}-3 w_{a}^{\prime} w_{b}{ }^{\prime}+12 w_{b}{ }^{2}\right) \\
& \left.+\left(v_{a}^{\prime 2}-3 v_{a}^{\prime} v_{b}^{\prime}+12 v_{b}^{\prime 2}\right)\right\}+\left[\frac{E I_{z}{ }^{\prime}}{45 l}\left(\theta_{b}-\theta_{a}\right)^{2}\right] \\
& c_{11,12}=-\frac{E A l}{1260}\left\{\frac{36}{l^{2}}\left(v_{b}-v_{a}\right)\left(w_{b}-w_{a}\right)\right. \\
& +\frac{3}{l}\left(v_{b}-v_{a}\right)\left(w_{a}^{\prime}-w_{b}^{\prime}\right)-\frac{3}{l}\left(w_{b}-w_{a}\right)\left(v_{a}^{\prime}-v_{b}{ }^{\prime}\right) \\
& \left.-w_{a}^{\prime}\left(2 v_{a}^{\prime}-3 v_{b}^{\prime}\right)+3 w_{b}^{\prime}\left(v_{a}^{\prime}-8 v_{b}^{\prime}\right)\right\}
\end{aligned}
$$




$$
\begin{aligned}
& c_{12,12}=\frac{E A l}{1260}\left\{\frac{54}{l^{2}}\left(v_{b}-v_{a}\right)^{2}+\frac{18}{l^{2}}\left(w_{b}-w_{a}\right)^{2}\right. \\
& -\frac{9}{l}\left(v_{b}-v_{a}\right)\left(v_{a}^{\prime}-v_{b}^{\prime}\right)+\frac{3}{l}\left(w_{b}-w_{a}\right)\left(w_{a}^{\prime}-w_{b}^{\prime}\right) \\
& +\left(w_{a}{ }^{\prime 2}-3 w_{a}{ }^{\prime} w_{b}{ }^{\prime}+12 w_{b}{ }^{\prime 2}\right) \\
& \left.+3\left(v_{a^{\prime 2}}-3 v_{a}{ }^{\prime} v_{b}{ }^{\prime}+12 v_{b^{\prime}}{ }^{2}\right)\right\}+\left[\frac{E I_{y}{ }^{\prime}}{45 l}\left(\theta_{b}-\theta_{a}\right)^{2}\right] \\
& c_{1, i}=c_{1, i+6}=c_{i, 7}=c_{7, i+6}=0 \quad(i=1,2, \cdots, 6)
\end{aligned}
$$

\section{【付録 2】}

式 (77) の付加剛性行列を示す. 式中, $I_{p}=I_{y}+I_{z}$, $I_{Q}=I_{y}-I_{z}$ なる記号を用いた。

$$
\begin{aligned}
& \text { (1) }\left[d_{i, j}\right] \\
& \begin{array}{l}
d_{1,1}=-d_{1,7}=d_{7,7}=\frac{3 E A}{2 l^{2}}\left(u_{b}-u_{a}\right) \\
d_{1,2}=-d_{1,8}=-d_{2,7}=d_{7,8}=\frac{18 E I_{z}}{l^{4}}\left(v_{b}-v_{a}\right)
\end{array} \\
& -\frac{9 E I_{z}}{l^{3}}\left(v_{a^{\prime}}+v_{b}{ }^{\prime}\right) \\
& d_{1,3}=-d_{1,9}=-d_{3,7}=d_{7,9}=\frac{18 E I_{y}}{l^{4}}\left(w_{b}-w_{a}\right) \\
& +\frac{9 E I_{y}}{l^{3}}\left(w_{a}^{\prime}+w_{b}^{\prime}\right) \\
& d_{1,5}=-d_{5,7}=-\frac{9 E I_{y}}{l^{3}}\left(w_{b}-w_{a}\right)-\frac{3 E I_{y}}{l^{2}}\left(2 w_{a}^{\prime}+w_{b}^{\prime}\right) \\
& d_{1,6}=-d_{6,7}=\frac{9 E I_{z}}{l^{3}}\left(v_{b}-v_{a}\right)-\frac{3 E I_{z}}{l^{2}}\left(2 v_{a}{ }^{\prime}+v_{b}{ }^{\prime}\right) \\
& d_{1,11}=-d_{7,11}=-\frac{9 E I_{y}}{l^{3}}\left(w_{b}-w_{a}\right) \\
& -\frac{3 E I_{y}}{l^{2}}\left(w_{a}^{\prime}+2 w_{b}^{\prime}\right) \\
& d_{1,12}=-d_{7,12}=\frac{9 E I_{z}}{l^{3}}\left(v_{b}-v_{a}\right)-\frac{3 E I_{z}}{l^{2}}\left(v_{a}{ }^{\prime}+2 v_{b}{ }^{\prime}\right) \\
& d_{2,2}=-d_{2,8}=d_{8,8}=\frac{18 E I_{z}}{l^{4}}\left(u_{b}-u_{a}\right) \\
& d_{2,6}=d_{\dot{2}, 12}=-d_{6,8}=-d_{8,12}=\frac{9 E I_{z}}{l^{3}}\left(u_{b}-u_{a}\right) \\
& d_{3,3}=-d_{3,9}=d_{9,9}=\frac{18 E I_{y}}{l^{4}}\left(u_{b}-u_{a}\right) \\
& d_{3,5}=d_{3,11}=-d_{5,9}=-d_{9,11}=-\frac{9 E I_{y}}{l^{3}}\left(u_{b}-u_{a}\right) \\
& d_{5,5}=d_{11,11}=\frac{6 E I_{y}}{l^{2}}\left(u_{b}-u_{a}\right) \\
& d_{6,6}=d_{12,12}=\frac{6 E I_{z}}{l^{2}}\left(u_{b}-u_{a}\right) \\
& d_{5,11}=\frac{3 E I_{y}}{l^{2}}\left(u_{b}-u_{a}\right) \\
& d_{6,12}=\frac{3 E I_{z}}{l^{2}}\left(u_{b}-u_{a}\right)
\end{aligned}
$$

その他の要素は 0 .

(2) $\left[e_{i, j}\right]$

$$
e_{2,3}=-e_{2,9}=-e_{3,8}=e_{8,9}=-\frac{3 E I_{Q}}{2 l^{3}}\left(\theta_{a}+\theta_{b}\right)
$$

$$
\begin{aligned}
& e_{2,4}=-e_{4,8}=\frac{3 E I_{Q}}{2 l^{3}}\left(w_{b}-w_{a}\right)+\frac{E I_{Q}}{2 l^{2}}\left(2 w_{a}{ }^{\prime}+w_{b}{ }^{\prime}\right) \\
& e_{2,5}=-e_{3,8}=-e_{5,8}=e_{6,9}=\frac{E I_{Q}}{2 l^{2}}\left(2 \theta_{a}+\theta_{b}\right) \\
& e_{2,10}=-e_{8,10}=\frac{3 E I_{Q}}{2 l^{3}}\left(w_{b}-w_{a}\right)+\frac{E I_{Q}}{2 l^{2}}\left(w_{a}^{\prime}+2 w_{b}^{\prime}\right) \\
& e_{2,11}=-e_{3,12}=-e_{8,11}=e_{9,12}=\frac{E I_{Q}}{2 l^{2}}\left(\theta_{a}+2 \theta_{b}\right) \\
& e_{3,4}=-e_{4,9}=\frac{3 E I_{Q}}{2 l^{3}}\left(v_{b}-v_{a}\right)-\frac{E I_{Q}}{2 l^{2}}\left(2 v_{a}{ }^{\prime}+v_{b}{ }^{\prime}\right) \\
& e_{3,10}=-e_{9,10}=\frac{3 E I_{Q}}{2 l^{3}}\left(v_{b}-v_{a}\right)-\frac{E I_{Q}}{2 l^{2}}\left(v_{a}{ }^{\prime}+2 v_{b}{ }^{\prime}\right) \\
& e_{4,5}=-\frac{E I_{Q}}{l^{2}}\left(v_{b}-v_{a}\right)+\frac{E I_{Q}}{4 l}\left(3 v_{a}^{\prime}+v_{b}^{\prime}\right) \\
& e_{4,6}=\frac{E I_{Q}}{l^{2}}\left(w_{b}-w_{a}\right)+\frac{E I_{Q}}{4 l}\left(3 w_{a}^{\prime}+w_{b}^{\prime}\right) \\
& e_{4,11}=e_{5,10}=-\frac{E I_{Q}}{2 l^{2}}\left(v_{b}-v_{a}\right)+\frac{E I_{Q}}{4 l}\left(v_{a}^{\prime}+v_{b}^{\prime}\right) \\
& e_{4,12}=e_{6,10}=\frac{E I_{Q}}{2 l^{2}}\left(w_{b}-w_{a}\right)+\frac{E I_{Q}}{4 l}\left(w_{a}{ }^{\prime}+w_{b}{ }^{\prime}\right) \\
& e_{5,6}=\frac{E I_{Q}}{4 l}\left(3 \theta_{a}+\theta_{b}\right) \\
& e_{5,12}=e_{0,11}=\frac{E I_{Q}}{4 l}\left(\theta_{a}+\theta_{b}\right) \\
& e_{10,11}=-\frac{E I_{Q}}{l^{2}}\left(v_{b}-v_{a}\right)+\frac{E I_{Q}}{4 l}\left(v_{a}^{\prime}+3 v_{b}^{\prime}\right) \\
& e_{10,12}=\frac{E I_{Q}}{l^{2}}\left(w_{b}-w_{a}\right)+\frac{E I_{Q}}{4 l}\left(w_{a}^{\prime}+3 w_{b}^{\prime}\right) \\
& e_{11,12}=\frac{E I_{Q}}{4 l}\left(\theta_{a}+3 \theta_{b}\right)
\end{aligned}
$$

その他の要素は 0 .

(3) $\left[f_{i, j}\right]$

$$
\begin{aligned}
& f_{2,4}=-f_{2,10}=-f_{4,8}=f_{8,10}=-\frac{E I_{p}}{4 l^{2}}-\left(w_{a}^{\prime}-w_{b}{ }^{\prime}\right) \\
& f_{2,5}=-f_{2,11}=f_{3,6}=-f_{8,12}=-f_{5,8}=-f_{6,9}=f_{8,11} \\
& =f_{9,12}=\frac{E I_{p}}{4 l^{2}}\left(\theta_{b}-\theta_{a}\right) \\
& f_{3,4}=-f_{3,10}=-f_{4,9}=f_{9,10}=-\frac{E I_{p}}{4 l^{2}}\left(v_{a}^{\prime}-v_{b}^{\prime}\right) \\
& f_{4,5}=-f_{5,10}=\frac{E I_{p}}{4 l^{2}}\left(v_{b}-v_{a}\right)-\frac{E I_{z}}{8 l}\left(v_{a}{ }^{\prime}+v_{b^{\prime}}\right) \\
& +\frac{E I_{y}}{8 l}\left(v_{a}{ }^{\prime}-v_{b}{ }^{\prime}\right) \\
& f_{4,6}=-f_{6,10}=\frac{E I_{p}}{4 l^{2}}\left(w_{b}-w_{a}\right)-\frac{E I_{z}}{8 l}\left(w_{a}^{\prime}-w_{b}^{\prime}\right) \\
& +\frac{E I_{y}}{8 l}\left(w_{a}^{\prime}+w_{b}^{\prime}\right) \\
& f_{4,11}=-f_{10,11}=-\frac{E I_{p}}{4 l^{2}}\left(v_{b}-v_{a}\right)+\frac{E I_{z}}{8 l}\left(v_{a}^{\prime}+v_{b}^{\prime}\right) \\
& +\frac{E I_{y}}{8 l}\left(v_{a}^{\prime}-v_{b}^{\prime}\right) \\
& f_{4,12}=-f_{10,12}=-\frac{E I_{p}}{4 l^{2}}\left(w_{b}-w_{a}\right)-\frac{E I_{z}}{8 l}\left(w_{a}^{\prime}-w_{b}^{\prime}\right) \\
& -\frac{E I_{y}}{8 l}\left(w_{a}^{\prime}+w_{b}^{\prime}\right) \\
& f_{5,6}=-f_{11,12}=-\frac{E I_{Q}}{8 l}\left(\theta_{b}-\theta_{a}\right)
\end{aligned}
$$




$$
f_{5,12}=-f_{6,11}=\frac{E I_{p}}{8 l}\left(\theta_{b}-\theta_{a}\right)
$$

その他の要素は 0 .

\section{参 考文 献}

1) Connor, J.J., R.D. Logcher and S.C. Chan : Nonlinear Analysis of Elastic Framed Structures, ASCE, Vol. 94, No. ST6, Proc. Paper 6011, pp. 1525 1547, June, 1968.

2) Tezcan, S.S. and B.C. Mahapatra : Tangent Stiffness Matrix for Space Frame Members, ASCE, Vol. 95, No. ST 6, Proc. Paper 6627, pp. 1257 1270, June, 1969.

3) Chu, K.H. and R.H. Rampetsreiter : Large Defdection Buckling of Space Frames, ASCE, Vol. 98, No. ST 12, Proc. Paper 9455, pp. 2701 2722, December, 1972.

4) 結城・前田：薄阶断面篟造の三次元挙動の解析, 土木学 会論文献告集, No. 224, 1974.

5) Oran, C. : Tangent Stiffness in Space Frames, ASCE, Vol. 99, No. ST 6, Proc. Paper 9813, pp. 987 1001, June, 1973.

6）坂井藤一：薄肉阳晰面御材の娞性安定基礎方程式の統一 的琇導, 上木学会䑳文報告集, No. 221， 1974.

7）西野・倉方・長浴川・奥村：軸力と曲げおよびねじりを 受ける薄肉断而部材, 上木学会論文報告集, No. 225 , 1974.

8）西野・蒼方・長谷川：論文 4) に対する討議, 土木学会 論文報告集, No. 239，1975.

9）西野文雄 : 曲げと軸力を受ける部材の解析, 構造力学公 式集発刊記念講漗会テキスト，1975.

10）国井修二郎・干田香苗：力学 I, 丸並, 1960 , pp. 57 70.
11）信原羍夫・桜井達美・吉村信敏 : コンピュータによる構 造工学講座 II -2-B, 培風館, 1972, pp. 83 88.

12）川井・村木：マトリックス法による船体構造解析に関す る研究 (IV), 日本造船学会論文集, No. 126, 1969.

13）前田・林・中村：増分法による平面骨組構造物の大変形 解析の加速計算法, 土木学会論文報告集, No. 223, 1974.

14） Desai, C.S. and J.F. Abel; 山本善之䓵 : マトリックス 有限要素法, 科学技術出版社, 1974.

15) Stricklin, J.A., W.A. Von Riesemann, J.R. Tillerson and W.E. Haisler : Static Geometric and Material Nonlinear Analysis, Advance in Computational Methods in Structural Mechanics and Design, The University of Alabama in Huntsville Press, pp. 301 324, 1972.

16) Gallagher, R.H. : Finite Element Analysis of Geometrically Nonlinear Problems, Theory and Practice in Finite Element Structural Analysis, University of Tokyo Press, pp. 109 123, 1973.

17）林正：構造物の非線形解析における多元連立方程式 の数倠解法, 京都大学数理解析研究所研究集会予稿集, 1975.

18）前田・林・伊奈：大三島橋の三次元的非線形性について, 土木学会第 29 回年次学術講演会講演概要集, I-108, 1974.

19）前田・林・森川：アーチ橋の面外非線形挙動について, 土木学会第 29 回年次学術講演会講演概要集, I-109, 1974.

20）前田・林・有岡：立体アーチの耐荷力について, 土木学 会第 30 回年次学術講演会講演概要集, I-82, 1975.

21）前田・林・中村：立体骨組構造物の大変形解析，昭和 49 年度土木学会 関西支部年次学術講演会 講演概要, I-1, 1974 .

(1976.1.31 - 受付) 